\title{
Flutuações econômicas, crise política e greve geral na Bahia da Primeira República ${ }^{1}$
}

Aldrin A. S. Castellucci Universidade do Estado da Bahia

\section{Resum O}

Em junho de 1919, eclodiu em Salvador a primeira greve geral da Bahia, rapidamente se expandindo para várias cidades do Recôncavo e convertendo-se no mais espetacular episódio da história da classe operária baiana em toda a Primeira República. Demonstramos, neste artigo, que tal movimento foi condicionado por três fatores, dois deles de caráter exógeno eum endógeno ao próprio movimento operário. Os condicionantes externos estão relacionados às flutuações econômicas derivadas da Primeira Guerra Mundial e à crise política criada pela cisão interoligárquica por ocasião das eleições estaduais efederais em 1919. O terceiro condicionante, de natureza endógena à classe operária, diz respeito às mudanças operadas em sua organização sindical e política. Conjugados, esses três elementos foram fundamentais para a eclosão e vitória do movimento. Palavras-Chave: Classe operária; Sindicatos; Greves.

\section{ABSTRACT}

In June 1919, it was deflagrated the first general strikein Bahia, rapidly spreading out towardsmany other cities of the "Recôncavo" area and becoming the most spectacular episode of the Bahia's working class history in the whole Brazil's " 1 st Republic" period. It will be demonstrated in this article that such a social mobilization was determined by threefactors, two of which having an exogenous nature, and the third one being inherent in the working men's mobilization itself. The exogenous factors are linked to the economic ups and downs due to the World War I and to the 1919's crisis. The third factor, inherent in the working class itself, refers to changes occurred in its trade unions and political structure. Held together, these three factors were fundamental for the start-up and success of this social mobilization.

Keywords: Working class; Trade Unions; Strikes. 
O final da década de 1910 foi marcado por grandes transformações econômicas, sociais e políticas e por uma intensa mobilização da classe trabalhadora no plano mundial. Parte dessas mudanças e desse processo de reorganização dos trabal hadores está associada, direta ou indiretamente, à Primeira Guerra Mundial (1914-1918). A eclosão do conflito militar provocou uma cisão no movimento operário que se organizava tendo por referência a II Internacional (1889-1914). 0 apoio que setores significativos da social-democracia deu aos governos em seus planos bélicos e imperialistas, até mesmo votando favoravelmente à liberação de créditos de guerra nos parlamentos nacionais, fez os descontentes se constituírem num pólo aglutinador de forças de esquerda expresso na fundação da III Internacional (1919-1943). As duas revoluções que eclodiram na Rússia entre fevereiro e outubro de 1917, juntamente com as insurrei ções na Alemanha e no resto da Europa formam o pano de fundo do movimento operário e sindical da época. Não éà toa que a conjuntura de 1917-1919 tenha sido marcada por intensas agitações operárias em todo o mundo. ${ }^{2}$

No Brasil, as greves assumiram contornos nunca vistos, abarcando diversos ramos e paralisando cidades, regiões e setores econômicos inteiros, pairando no ar uma perspectiva de profundas reformas sociais que melhorassem ou mesmo transformassem radicalmente as condições de vida da classe trabalhadora em geral. Assim, entre os dias 9 e 16 de jul ho de 1917, os anarquistas de São Paulo conseguiram, após um longo processo de construção do movimento em sintonia com os socialistas, fazer eclodir aquela quefoi a maior greve geral do período, ficando imortalizada e retida de maneira mais significativa na memória do movimento operário, influenciando a própria classe operária de outras unidades da Federação e inspirando um razoável número de trabalhos acadêmicos. ${ }^{3} \mathrm{O}$ movimento rapidamente se expandiu para cidades do interior daquele estado e para o Rio de Janeiro, onde tomou contornos próprios desde o dia 14 de julho. ${ }^{4}$ Ainda em fins de julho de 1917, o conflito seguido de novas greves gerais alastrou-se para áreas distantes do centro industrial do país e atingiu as cidades gaúchas de Porto A legre ( 1 - a 5 de agosto $)^{5}$ e Pelotas ( 9 a 17 de agosto). ${ }^{6}$ Em outubro de 1918, uma nova greve geral foi desencadeada na cidade de Rio Grande (RS) eno mês seguinte uma insurrei ção anarquista foi sufocada e violentamente reprimida no Rio de Janeiro. ${ }^{7}$ Em 1919, outras greves gerais foram desencadeadas em Rio Grande ( 5 a 21 de maio), Salvador ( 2 a 12 de junho), Recife (fins de junho) ${ }^{8}$ e Porto Alegre (25 de agosto a 11 de setembro). Entretanto, é preciso deixar claro desde já que admitir conexões entre o movimento baiano e o dos outros estados não 
implica dizer que as greves de Salvador e das demais cidades do país tenham sido meros efeitos de demonstração do movimento original de São Paulo. 0 movimento operário da Bahia e de cada uma das unidades federativas do Brasil guarda semelhanças, mas também peculiaridades, e teve características, dinâmicas e reivindicações que não podem ser reduzidas a um modelo construído a partir da realidade do centro do país. Como já se observou, a história operária brasileira poderá alcançar um outro patamar analítico a partir da articulação das pesquisas regionais, ou seja, do cruzamento das informações sobre a vida e o movimento da classe operária nos vários estados brasileiros. ${ }^{9}$

Dando seguimento à leitura da bibliografia, percebemos que a produção acadêmica acerca do movimento operário e sindical baiano durante a Primeira República era extremamente rara. Entre os poucos estudos existentes sobre o tema, vale a pena mencionar os artigos dos irmãos Rubim, os quais procuravam explorar as relações entre o movimento operário e a imprensa ligada às elites, procedendo a um mapeamento das posições políticas e ideológicas que os principais órgãos da imprensa local assumiram, na conjuntura de 1917 a 1921, frente às demandas do operariado. Por meio do confronto e da análise dos jornais ligados a J. J. Seabra e ao Partido Republicado Democrata e dos órgãos da oposi ção vinculada a Ruy Barbosa, juntamente com um levantamento resumido dos principais fatos ocorridos naqueles anos, aqueles autores chegaram a esboçar a dinâmica das greves e dos conflitos interoligárquicos que marcaram o período. ${ }^{10} \mathrm{~A}$ dissertação de mestrado, infelizmente ainda não publicada, de José Raimundo Fontes foi, no entanto, o primeiro estudo de história operária de maior fôlego, apresentando um levantamento exaustivo e bem documentado sobre a incidência de greves e reivindicações dos trabal hadores na Bahia durante toda a Primeira República, sendo a abrangência da pesquisa e seus ganhos em termos de conhecimento das tendências gerais do movimento grevista e de suas conjunturas de maiores ou menores fluxos os principais méritos do trabal ho. ${ }^{11}$ Por último, é preciso lembrar a tese de doutorado de M ário Augusto da Silva Santos, na qual o operariado baiano da República Velha aparece, mesmo que de modo diluído, num estudo sobre as diversas formas de luta pela sobrevivência que as classes populares de Salvador empreenderam no período, especial mente contra a carestia dos gêneros de primeira necessidade e a especulação imobiliária com as habitações populares. $^{12}$

A riqueza histórica do período e o silêncio da bibliografia especializada aguçaram a nossa curiosidade em conhecer melhor os acontecimentos de 1919 na Bahia, brevemente relatados pelos autores citados. Questionávamos, entre 
outras coisas, a natureza do sindicalismo baiano e os motivos pel os quais a greve geral baiana ocorreu em 1919 e não em 1917. Os dois problemas, apesar de formulados de modo separado, estão intimamente relacionados, como mostraremos. Pretendemos demonstrar, no presente artigo, que a greve geral de junho de 1919 em Salvador foi condicionada por três fatores, dois deles de caráter exógeno e um endógeno ao próprio movimento operário. Os condicionantes externos estão relacionados às flutuações econômicas derivadas da Primeira Guerra M undial e à crise política criada pela cisão interoligárquica por ocasião das el eições para governador do estado e presidente da República em 1919. 0 terceiro condicionante, de natureza endógena à classe operária, diz respeito às mudanças operadas em sua organização sindical e política. Conjugados, esses três fatores foram fundamentais para a eclosão e vitória do movimento operário em 1919.

\section{FLUTUAÇÕES ECONÔMICAS E CRISE SOCIAL}

A Primeira Guerra Mundial provocou profundas perturbações na economia capitalista mundial, e o Brasil não se constituiu numa exceção. As dirigir todas as energias internas para o esforço de guerra e converter a maior parte de seus parques produtivos em indústria bélica, as nações européias beligerantes terminaram por demandar dos países periféricos um esforço crescente para abastecê-las dos produtos primários de que necessitavam para alimentar suas populações e exércitos. Por sua vez, ao incrementarem suas exportações de arroz, açúcar, batata, carnes, farinha de mandioca, feijão e miIho, entre outros produtos, os países da periferia do sistema, como o Brasil, resolviam seus problemas de balança comercial, até mesmo conseguindo saldos positivos, mas o custo social disso era muito alto, pois a população sofria com os problemas relacionados à escalada dos preços dos gêneros de primeira necessidade, à escassez do pão, aos aluguéis cada vez mais caros e à falta de moradia adequada. A inflação atingiu níveis tão altos, que arruinou a já frágil economia popular, sendo alvo de várias manifestações populares por todo 0 Brasil e especial mente na Bahia, onde se destacou a liderança do rábula Cosme de Farias e seu Comitê Popular Contra a Carestia deVida, que se reunia periodicamente na sede do Centro O perário da Bahia e da Sociedade M ontepio dos Artistas. ${ }^{13}$

Esses fatos afetaram a vida cotidiana dos trabal hadores, mas de forma ainda um tanto lateral. A classe operária incorpora-se como força de traba- 
Iho no processo social global de produção. Para se compreender melhor como os operários sentiram e viveram os anos da guerra é preciso, portanto, sair da esfera do consumo e penetrar no mundo do trabalho. Saber qual foi o impacto da guerra sobre as atividades produtivas das quais os trabalhadores retiravam o seu ganha-pão é, assim, fundamental. ${ }^{14}$

$\mathrm{Na}$ Bahia, o mais importante ramo de produção, do ponto de vista econômico, era, indiscutivelmente, o têxtil, sendo possível perceber três períodos nitidamente definidos de sua situação durante a guerra. Se tomarmoso ano de 1912 como pico de um período de relativa estabilidade anterior ao conflito, veremos que, do ponto de vista da evolução dos lucros, essa indústria viveu sua crise mais aguda nos anos 1913-1914, quando houve diminuição drástica das vendas, retração do crédito bancário, agravamento da crise de superprodução e venda dos estoques a preços abaixo dos praticados no mercado em tempos normais. Começou a se recuperar em 1915-1916 e gozou de uma real prosperidade, a despeito das negativas e reclamações de seus diretores, algumas delas reais, outras não, durante o período de 1917 a 1920. Em meio a esta última fase e imbricando-se com ela, temos uma conjuntura específica de crise profunda no imediato pós-guerra, do segundo semestre de 1918 ao primeiro trimestre de 1919, que não afetou a margem de lucros dos industriais, mas que trouxe um mal-estar social nunca visto para a maioria dos operários têxteis, pois os industriais resolveram seus problemas de superprodução fechando algumas fábricas e/ou diminuindo o número de dias e horas de trabalho. Embora nenhuma dessas conjunturas específicas tenha sido absolutamente fechada e cada uma delas guardasse elementos da que lhe antecedeu ou sucedeu, compartilhando-os, é possível dizer que houve uma crise de superprodução jamais experimentada pela indústria têxtil, mas, como veremos, quem arcou com todo o ônus foram os trabalhadores.

Vejamos alguns exemplos: A Companhia Empório Industrial do N ortetevelucroslíquidos de 739:504\$490 em 1912, mas estes caíram para 408:060\$660 em 1913 e despencaram para 168:818\$970 em 1914. Em 1915 a empresa começou a recuperar-se, alcançando lucros de 686:893\$640, e depois $657: 419 \$ 280$ em 1916, 813:308\$980 em 1917, 857:467\$110 em 1918, 859:147\$270 em 1919 e 2.116:441\$450 em 1920.15 Já a Companhia Progresso Industrial da Bahia, detentora de quatro fábricas, teve lucros de 770:299\$070 em 1912, que caíram para 315:874\$250 em 1913 e despencaram para 122:035760 em 1914, mostrando sinais de recuperação em 1915, nova queda em 1916 e um padrão crescente de retomada dos negócios a partir de 1917, quando passou a ter lucros superiores a 843:053\$720, atingindo a marca de 
1.371:360\$980 em 1920. ${ }^{16}$ As duas fábricas da Companhia Valença Industrial apresentaram modestos lucros de 466:963\$136 em 1912, crescimento em 1914 com 675:300\$455 e queda para 276:235\$730 em 1915, recuperando-se a partir de 1916 com 426:350\$540, 644:783\$910 em 1917, 1.209:494\$790 em 1918, 1.546:655\$630 em 1919 e 1.604:950\$530 em 1920. ${ }^{17}$ A Companhia Fabril dos Fiais, com uma única fábrica de juta, apresentou lucros brutos estáveis, tendo tido resultados de 781:003\$510 em 1912 e um valor variável entre 1.000:000\$000 e 2.000:000\$000 entre 1915 e 1920. ${ }^{18}$ A Companhia União Fabril da Bahia, proprietária de seis fábricas, foi a que teve a maior variação em seus Iucros líquidos: 822:432\$550 em 1913, 1.077:942\$100 em 1914, 465:934\$130 em 1915, 560:950\$000 em 1917, 819:231\$350 em 1918, 763:407\$160 em 1919 e 1.414:731\$390 em 1920.19

Independentemente da existência concreta de fases mais críticas de crise, recuperação ou mesmo de prosperidade, os industriais têxteis queixaramse, durante todo o perío do da guerra, dos fatores que provocaram aumento dos custos de produção e diminuição da margem de lucro das fábricas, particularmente os ligados à escalada dos preços dos insumos, tais como carvão, anilinas, óleos combustíveis, lubrificantes e algodão, além das pragas da lagarta-rosada e da lagarta-verde, lamúrias que apareceram fartamente nos relatórios aqui citados. Uma das formas de enfrentar tais problemas, ou seja, reduzir os custos de produção, aumentar a produtividade e valorizar os seus produtos foi a paralisação parcial ou total da produção de algumas unidades e a ampliação, ao máximo, da produção de outras, tarefa relativamente fácil, já que três das cinco companhias existentes no estado possuíam mais de uma fábrica. Os relatórios oficiais e os já citados servem para sistematizar essas informações para todas as fábricas, mostrando claramente que os efeitos negativos da crise gerada pela guerra foram sentidos de maneira mais intensa pelos operários têxteis nos anos de 1914 a 1917, quando a taxa de desemprego alcançou um nível muito alto em função da paralisação parcial ou total, temporária ou de longo prazo, de pelo menos oito das fábricas existentes. Das catorze unidades de produção desse setor, para as quais temos informações precisas, apenas seis funcionaram de modo regular eininterrupto de 1912 a 1920. Assim, em 1912 e 1913, apenas três fábricas estavam paralisadas, número que aumentou para seis em 1914. Em 1915, já eram cinco totalmente paralisadas e duas funcionando parcialmente, e em 1916 e 1917, tínhamos seis fechadas ou operando precariamente. Foi apenas em 1918-1919 que começamos a nos aproximar outra vez dos padrões anteriores à grande crise de 1913. Para asse- 
gurar o lucro, não era raro um industrial fechar uma de suas fábricas, contratar um número menor de indivíduos do que o conjunto de operários despedidos e alocá-los numa segunda unidade, ampliando a jornada de trabal ho de todo o grupo, até mesmo com serões noturnos e contratação em massa de mulheres e menores a salários ainda mais depreciados.

Com base nessas estatísticas, pode-se ver também que em 1918 e 1919 a oferta de emprego na indústria têxtil cresceu de forma sensível, graças à incorporação de duas novas fábricas e, fundamentalmente, ao aumento do número de operários contratados por unidade de produção. Fábricas que estavam paral isadas voltaram a funcionar a toda força ou parcialmente, enquanto outras ampliaram o tamanho de suas plantas eaumentaram o número de seus teares e postos de trabalho. Em 1918 e 1919, o número de postos de trabalho na indústria têxtil era maior do que em 1912, ano anterior à grande crise internacional de 1913. Assim, em 1912, as cinco companhias têxteis e suas catorze fábricas ofereciam 5.279 postos de trabalho; em 1913 eram 5.280, em 1914 o número caiu para 3.950, houve uma pequena recuperação em 1915, com 4.300 vagas, em 1916 havia 4.820, em 1917 o número chegou a 4.900 e em 1918 alcançou níveis maiores que os de antes do colapso de 1913, com 6.200 postos, mantendo o mesmo número em 1919 e apresentando uma alta pouco significativa em 1920 , com $6.230 . .^{20}$

M as não nos enganemos. A análise desses dados sem uma confrontação com fontes mais qualitativas pode levar a uma impressão equivocada acerca das reais condições de existência dos operários têxteis. Essa não foi uma fase de elevação do nível de vida desses operários. Por detrás da aparente estabilidade no emprego escondia-se uma conjuntura de profunda depressão salarial e deterioração das condições de trabalho dos operários. Além disso, é preciso notar que no segundo semestre de 1918 e até o primeiro trimestre de 1919 a indústria têxtil viveu um prolongado período de crise de superprodução. 0 comércio atacadista cancel ou encomendas anteriormente feitas e suspendeu todos os pedidos novos, al egando já dispor de um estoque não vendido incompatível com a sua capacidade de comercialização. Asfábricastêxteis alegaram ter prejuízos imediatos, com a paralisação das entregas, a ampliação dos seus próprios estoques e a conseqü ente desval orização de seus tecidos, justificativa perfeita para manter os salários depreciados.

Em fins de julho de 1918, o jornal 0 Tempo, porta-voz oficioso do governo chefiado pelo Partido Republicano Democrata do governador Antonio Ferrão M oniz deAragão e do então senador J. J. Seabra, publicou uma série de matérias e editoriais nos quais advogava a realização de uma "campanha 
redentora em prol do proletariado". Argumentava que era um órgão de imprensa pugnando pela defesa dos interesses coletivos, pela justiça e pela razão, respeitando os poderes constituídos e a ordem pública, asseguradora do progresso e da prosperidade do povo, elembrando os ideais de liberdade e igualdade supostamente inaugurados pela República fundada em 15 de novembro de 1889. Desta forma, o editor procurava justificar e embasar a sua intervenção em defesa dos operários naquele momento. ${ }^{21}$

O jornal procurou refutar a idéia de que os industriais enfrentavam momentos difíceis, denunciando que todos os aumentos dos insumos haviam sido repassados para os preços diretos ao consumidor. Na defesa dos dois mil operários da Companhia Empório Industrial do N orte (CEIN ), denunciava-se também que os operários eram contratados sob o regime de empreitada combinada com metas previamente estabelecidas, mas, como a remuneração por peça era muito baixa, os adultos do sexo masculino estavam recebendo entre $12 \$ 000$ e $13 \$ 000$ por semana, menos de _ dos $50 \$ 000$ que poderiam ser feitos antes da guerra. As mulheres recebiam a metade ou menos, algo entre $5 \$ 000$ e $7 \$ 000$ pela mesma empreitada semanal. Ambos deveriam produzir, no mínimo, uma peça de pano de 120 metros a cada cinco dias dentro de uma jornada de trabalho diária de dez horas, que começava às seis e meia da manhã, prolongando-se até as cinco e meia da tarde. Já os inúmeros menores dos dois sexos eram jornal ei ros e recebiam ainda menos, isto quando recebiam salários, posto que era comum o trabalho infantil em troca apenas da aprendizagem de um ofício, comida, alojamento e roupas. Todos os salários sofriam, ainda, reduções semanais referentes a aluguéis na vila operária e multas cobradas por defeito nos tecidos. Esses fatos eram tão freqüentes que segundo as fontes consultadas, no segundo semestre de 1918, por várias vezes os ganhos dos operários ficaram reduzidos a zero. Um elemento catalisador das insatisfações foi a denúncia de que um al to funcionário da CEIN estava, juntamente com seu filho, praticando agiotagem contra os operários. Aproveitando-se da situação de penúria dos trabalhadores e contando com a leniência da empresa, o preposto fazia-Ihes pequenos adiantamentos de seus próprios salários em troca de juros de 20 por cento por semana. Além disso, a situação de pobreza dos operários contrastava com a opulenta situação de seu al goz, que ganhava $400 \$ 000$ mensais e era dono de várias propriedades. O jornal chegou a denunciar que o esquema montado pelos funcionários do escritório era lesivo e implicava subtração de recursos da própria empresa, e exigiu que a companhia aumentasse em, no mínimo $1 \$ 000$, o valor da empreitada. Alegava que os operários daquela empresa estavam levando uma vi- 
da ignóbil e sem nenhuma garantia para si e para suas famílias, e ameaçava orquestrar uma campanha que levaria a uma greve, caso suas exigências não fossem atendidas. A tensão continuou durante os meses seguintes, mas a situação, ao invés de melhorar, piorou, principalmente a partir de novembro de 1918. O s armazéns estavam com enormes estoques de mercadorias sem saída, e as fábricas têxteis com grande quantidade de al godão comprado no período de alta. Q uando a guerra acabou, os preços dessa matéria-prima despencaram, eas companhias ficaram com um estoque do insumo que puxava seus custos de produção para cima, mas que não encontrava correspondência nos preços de seus produtos colocados no mercado. A CEIN diminuiu, então, de forma drástica o número de horas e dias de trabalho. A Fábrica da Boa Viagem passou a funcionar apenas quatro dias na semana em vez dos seis anteriores à crise. Os salários dos operários sofreram uma redução na mesma proporção e estes entraram numa situação de desespero, relatada em carta ao editor de 0 Tempo. Segundo eles, depois de realizados os descontos de multas e aluguéis, nada recebiam aos sábados, estando a fome rondando os lares na vila operária da fábrica. Esta situação de subemprego e compressão salarial na CEIN perdurou até maio de 1919, quando novas encomendas foram feitas e os negócios em geral foram reativados, abrindo um novo ciclo de prosperidade para o setor. Situação semelhante ocorreu nas fábricas Conceição, São J oão e Paraguaçu, onde o trabalho seria paralisado por 8 a 15 dias após o Natal de 1918.22

O ramo de produção de vestuário e toucador também passou por dificuldades provocadas, direta ou indiretamente, pela Primeira Guerra M undial. Desde pelo menos janei ro de 1917, a imprensa denunciava que trustes norte-americanos e europeus estavam comprando toda a produção de couros da Bahia e de outros estados, exportando-a para abastecer suas fábricas nos Estados Unidos e na Inglaterra. De fato, os armazéns da Companhia das D ocas do Estado da Bahia estavam empanturrados de couros e peles para serem exportados. M as se antes da guerra, parte dessa matéria-prima era enviada ao exterior para ser curtida e retornava ao Brasil para ser utilizada nas fábricas locais, agora a viagem era só de ida, ocasionando escassez e alta dos insumos para as fábricas de cal çados existentes em Salvador. A Fábrica Stella, por exemplo, al egava que a sola de primeira qualidade, que em novembro de 1916 custava $3 \$ 000 /$ quilo, passara a custar $6 \$ 500 /$ quilo em janeiro de 1917 , e que a pelica preta, que em julho de 1916 custava 17 centavos por pé quadrado nos Estados Unidos, passara a custar, em janeiro de 1917, 68 centavos, fato que determinou um aumento de 20 por cento nos seus preços. Na Fábrica 
Trocadero a situação não era diferente. Seu diretor chamava a atenção para o fato de que, de janeiro de 1916 a janeiro de 1917, o quilo de sola pulara de $2 \$ 800$ a $7 \$ 000 /$ quilo. A Carneira da Bahia, amarela e preta, que na alta estação já custava $52 \$ 000 /$ dúzia, passou para $110 \$ 000$ em janeiro de 1917. Já os forros, que custavam de 700 a 800 réis/metro, passaram a custar $1 \$ 200$ e $1 \$ 400 /$ metro em janeiro de 1917 . 0 próprio preço dos calçados subiu 100 por cento em relação a janeiro de 1916, e a fábrica estava ameaçando paralisar a sua produção, a começar pelos sapatos mais populares. ${ }^{23}$

No ano da greve geral, a situação de crise vivida por essa indústria não parecia ter sido inteiramente superada, principalmente se considerarmos que as exportações brasileiras de matérias-primas necessárias ao processo produtivo das fábricas de calçados, longe de terem diminuído, aumentaram sensivelmente. Em 1918, as exportações de couros da Bahia haviam chegado a 42.281 toneladas, ao passo que em 1914, haviam sido de apenas $29.569,{ }_{1}^{24}$ e até outubro de 1919, as exportações daquela matéria-prima já haviam atingido 51.358 toneladas. ${ }^{25}$ De alguma forma, entretanto, a ameaça de paralisação das fábricas não parece ter se concretizado. Contudo, se os operários sapatei ros viviam sobressaltados com a ameaça da perda do emprego, pior aconteceu com os chapeleiros. Durante a conjuntura em análise, o setor parecia francamente estagnado e em retrocesso na Bahia. Para piorar a situação, sua principal fábrica, a Companhia Chapelaria Norte Industrial, foi consumida por um incêndio em abril de 1918, deixando seus quinhentos operários sem trabalho. ${ }^{26}$

É preciso salientar, também, as condições de profunda exploração e pobreza das operárias de manufaturas de roupas e costureiras dos ateliês da cidade, situação que não parece ter mudado de modo significativo nem mesmo depois da greve geral de 1919. Prova disso é que, em março de 1921, o grupo vinculado ao Sindicato dos Pedreiros, Carpinteiros e D emais Classes e ao jornal A Voz do Trabalhador denunciou a opressão vivida pelas operárias que trabaIhavam sob o regime de "costuras de carregação". Por ele, as trabal hadoras entravam nas manufaturas e labutavam das seis horas da manhã às seis horas da tarde, recebendo, segundo o articulista, a insignificante quantia de $\$ 200$ por calça entregue pronta, caseada e com botões. 0 jornal dizia ser preciso que a operária fosse "forte eligeira" para que, dentro daquela extenuante jornada de trabalho, conseguisse costurar oito calças, pelas quais receberia $1 \$ 600$, dos quais seriam descontadas, ainda, as despesas com linhas, agulhas e carreto.

Nas camisarias, a situação não era melhor. Seus proprietários pagavam entre $\$ 500$ e $\$ 600$ por uma dúzia de mangas, $\$ 700$ por uma dúzia de peitiIhos, $\$ 200$ por uma dúzia de punhos, $\$ 100$ por uma dúzia de presilhas, $\$ 500$ 
por uma dúzia de pélas, \$200 por uma dúzia de bainhas, \$100 para pregar botões em uma dúzia de camisas e \$100 para repassar. Além dos baixíssimos valores recebidos pelas empreitadas, as costurei ras ainda tinham de arcar com os custos relativos à aquisição de linhas, enquanto outros estabel ecimentos realizavam descontos de até $\$ 300$ nos salários das operárias que tivessem suas agulhas quebradas durante o processo de trabal ho, não obtendo emprego "as que não querem se sujeitar a semelhante roubalheira". Por sua vez, as engomadeiras ganhavam entre $1 \$ 000$ e $2 \$ 000$ por dúzia de peças, variando deacordo com a "obra". As que trabal havam em casa, por exemplo, recebiam um valor entre $3 \$ 000$ e $3 \$ 500$ por dúzia de camisas. Em resumo, essas operárias trabalhavam durante uma semana inteira para ganhar algo entre $7 \$ 000$ a $8 \$ 000$, e as pregadei ras de botões e as repassadei ras ganhavam, no máximo, 4\$000 por semana, além de sofrerem com a prática do assédio sexual. ${ }^{27}$

Situação semelhante de crise setorial prolongada também afetou a vida dos trabal hadores da construção civil em função da paralisação das obras de remodelamento e modernização de Salvador. A primeira gestão de J. J. Seabra à frente do governo estadual (1912-1916) fora marcada pelas obras de aterro do Cais do Porto, alargamento de inúmeras ruas da Cidade Baixa, abertura da Avenida Sete de Setembro, principal via da Cidade Alta, e sua interligação com a O rla M arítima através da Avenida O ceânica. Além disso, procedeu-se também a reformas, construções, demolições e reconstruções de edifícios públicos. ${ }^{28}$ Tantas obras e edificações trouxeram para o mercado de trabalho soteropolitano centenas de operários da construção civil, que vieram de toda parte do estado, de outras regiões do país ( principalmente São Paulo e Rio de Janeiro) e mesmo do exterior, especialmente de Portugal. ${ }^{29}$ Em 1913, apesar da grande crise internacional e de seus efeitos sobre o país, avenidas foram rasgadas, ruas alargadas e Passos levantados; casas, pavilhões e jardins foram surgindo; muitos muros, calçadas, meios-fios e revestimentos foram feitos ou refeitos; fachadas, cúpulas e torres foram erguidas. As obras eram realizadas na Orla, no Centro e na Cidade Baixa, a maioria a cargo do Estado, mas também se viam as da União e da Inten dência, além das da iniciativa de particulares e de empresas que também não faltavam. Em 1914, os recursos foram se tornando mais escassos e os materiais começaram a faltar, além de estarem cada vez mais caros e só poderem ser pagos à vista. As obras, então, tornaramse mais lentas e algumas foram suspensas ou paralisadas. Os pagamentos aos empreitei ros começaram a ser efetuados por meio de apólices e depois por meio do empréstimo popular de 1914. Os próprios operários da construção civil fizeram greves em novembro de 1913 e fevereiro de 1914, reivindicando 
o pagamento de salários atrasados. A modernização ea remodelação haviam sido parcialmente alcançadas, mas quando a euforia acabou e os empréstimos dos banquei ros pararam de regar os cofres públicos, as obras sofreram uma paral isação geral. 0 enorme contingente operário, contratado e estabelecido na cidade nos anos anteriores, rapidamente converteu-se num grande exército industrial de reserva e um período de desemprego, subemprego, compressão salarial e fome se abriu para esse setor..$^{30}$ Os efeitos negativos da profunda retração das atividades relacionadas à construção civil ainda se faziam sentir de modo vigoroso no início de 1919. A guerra havia provocado altas tão grandes nos preços dos insumos, que os pequenos empreiteiros e mestres da construção preferiam não construir a correr o risco de uma virtual falência, um perigo alto em se tratando de um setor tão pouco capitalizado. ${ }^{31}$

O final da guerra, em 1918, assinalou portanto não apenas um curto e doloroso período de agravamento da crise que já vinha se desenrolando desde 1913, seguida de momentos de recuperação e novas depressões. Quando os males da superprodução se foram, a partir do segundo trimestre de 1919, uma nova etapa se abriu para a história da classe operária da Bahia. As agruras da crise de guerra tinham ficado marcadas na memória, os rancores contra a ampliação da exploração feita pelos industriais, muito particularmente no que tange à jornada de trabal ho e à compressão salarial, e os horrores da especulação e carestia dos preços dos gêneros de primei ra necessidade haviam se cristalizado. O s industriais ago ra buscavam mais mão-de-obra, pois estavam abarrotados de encomendas. As máquinas funcionavam a toda força. 0 ritmo das atividades portuárias e comerciais havia voltado ao normal. Para muitos setores, a exemplo dos têxteis, o risco de desemprego havia se reduzido a um patamar insignificante. Junto com a nova maré de prosperidade, vieram as aspirações de um novo mundo. As condições objetivas para a revanche estavam dadas. Alguns líderes operários e socialistas perceberam isso. A vez da classe operária tinha chegado...

\section{AS ELEIÇÕES DE 1919 E A CRISE INTEROLIGÁRQUICA}

Contudo, apenas o início de um novo ciclo de prosperidade econômica não seria suficiente para desencadear um movimento da envergadura e com as características da greve geral de junho de 1919 em Salvador. As relações de determinação entre o econômico e o político não são mecânicas nem simples. 0 quadro traçado do período de crise e recuperação econômica é essen- 
cial para contextualizar a ação dos trabalhadores, porém pelo menos mais dois outros fatores foram importantes para que o movimento operário tomasse as proporções que acabou ganhando efosse vitorioso, conforme já dissemos.

Diferentemente do que ocorreu em outros estados do país, na Bahia não surgiu uma oligarquia hegemônica que fosse capaz de assegurar a estabilidade das instituições do novo regime. A acirrada competição fazia da política uma área de conflitos muito intensos e, por vezes, sangrentos. Não por um acaso, intervenções federais foram realizadas em 10 de janeiro de 1912, 23 de fevereiro de 1920 e 19 de março de $1924 .{ }^{32}$

N esse quadro de conflitos, o ano de 1919 ganhou, no entanto, características que o tornaram singular, pois as el eições para a presidência da República e para o governo estadual aprofundaram a cisão das elites baianas. N os dois casos, as antigas oligarquias se realinharam em torno da liderança de Ruy Barbosa contra Seabra e o PRD. Em janeiro, o presidente Rodrigues Alves, el eito para o quatriênio de 1918-1922, não resistiu à gripe espanhola e faleceu. Pelas regras da política do café-com-leite, o mineiro Wenceslau Brás deveria ter sido empossado. Contudo, D elfim Moreira, o vice de Rodrigues Alves, acabou assumindo interinamente, realizando, conforme prescrevia a norma constitucional, novas el eições. Da falta de consenso entre as oligarquias dominantes de São Paulo e M inas Gerais, surgiu o nome de Epitácio Pessoa, da Paraíba, que passou a contar com o apoio daqueles dois estados principais e do Rio Grande do Sul, Pernambuco e Bahia. ${ }^{33}$ Seu nome foi referendado na Convenção da Situação, realizada no Senado da República, Rio de Janeiro, a 25 de fevereiro. Opondo-se a Ruy Barbosa tanto no plano nacional quanto no estadual, Seabra e outros políticos do PRD lançaram-se na campanha de Epitácio Pessoa e já em princípios de março o candidato chegava a Salvador para iniciar os embates contra seu conterrâneo e colega de Senado. Derrotados em sua nova Campanha Civilista, os ruístas mantiveram-se inconformados durante todo o ano e lançaram uma enxurrada de denúncias de corrupção e malversação de verbas públicas contra o governador Antônio M oniz nas páginas de seus jornais. E, aproveitando-se do fato de o presidenteEpitácio Pessoa ter relaxado a política dos governadores, reagruparam-se para apoiar a candidatura do juiz federal Paulo Fontes ao governo estadual nas eleições de 29 de dezembro. 0 conflito interoligárquico havia chegado a tal ponto que as antigas lutas sangrentas entre os coronéis do sertão, amainadas pela trégua de 1915, recrudesceram outra vez em meados de 1919 nas Lavras Diamantinas, atingindo o ponto mais dramático da contenda que já durava dois anos entre 
os partidários de Horácio de M atos, futuro aliado de Ruy Barbosa, e os chefes locais do PRD, que solicitaram ao governador Antonio Ferrão M oniz deAragão o envio de tropas policiais para enfrentar o potentado inimigo, o que efetivamente foi feito em junho e julho de 1919.34

A quebra radical e definitiva do monolitismo das elites baianas da Primeira República trouxe conseqüências importantes para o movimento operário. A cisão e o conflito interoligárquico, no peculiar ano de 1919, fizeram que tanto seabristas quanto ruístas buscassem apoio da classe operária em suas disputas. Durante a greve geral de junho, essa política será levada ao limite por meio de uma permissividade extrema em relação ao movimento operário, que não será reprimido em nenhum momento pelas forças do Estado. Os próprios operários procurarão tirar o máximo de proveito da situação, trazendo o governo e os políticos do PRD para o seu lado na luta contra os industriais, empreiteiros, comerciantes e o patronato em geral. Aliás, essa não foi uma tarefa difícil, pois a Associação Comercial da Bahia e o Centro Industrial do Algodão haviam apoiado Ruy Barbosa em suas disputas contra J. J. Seabra e Antônio M oniz e agora era chegado o momento de pagarem por isso...

Sabe-se que em um confronto entre duas classes ou grupos sociais e/ou políticos polares não é incomum que um dos contendores - geralmente 0 mais fraco, pois se trata de uma relação assimétrica - busque trazer para a arena da luta de classes um terceiro elemento. Joan Bak observou que isso aconteceu no Rio Grande do Sul no momento das greves ferroviárias de juIho e outubro de 1917, quando os operários buscaram o apoio do governador Borges de M edeiros em sua luta contra a Compagnie Auxiliaire de Chemins de Fer. O movimento teve contornos claramente nacionalistas, apresentando-se como um combate dos brasileiros numa aliança pluriclassista (operários da empresa, populares e comerciantes usuários do sistema de transporte de pessoas e mercadorias e governo estadual) contra a exploração dos capitalistas estrangeiros, detentores da concessão da ferrovia federal ${ }^{35}$

Na Bahia, apesar da quase ausência do componente nacional, os operários e seus sindicatos aproveitaram-se da cisão no interior das elites políticas, fazendo que o conflito entre capital e trabalho se misturasse à luta da classe operária e das forças seabristas contra os ruístas e seus aliados político-eleitorais na burguesia mercantil, industrial e financeira local. Os problemas expostos no caso gaúcho também valem para o baiano, estando relacionados ao fato de que quanto mais se amplia a aliança pluriclassista, maior é o risco de o movimento operário tornar-se massa de manobra nas mãos de uma das frações da burguesia ou dos governos. Além disso, ao assumirem os riscos, os 
trabalhadores influenciaram os rumos da própria política estatal em relação ao movimento operário. Considerando o quadro político e o fato de que numa aliança dessa natureza os interesses são mútuos, ou seja, da classe operária para as elites e das elites para a classe operária, tais problemas foram resumidos em três questões por Joan Bak: as condições da aliança, o grau de independência de classe e influência na aliança, e a utilidade desta para os interesses dos operários. A dinâmica e os desdobramentos da aliança da classe operária baiana com uma das frações oligárquicas em 1919 e nos dois anos subseqüentes serão analisados a seguir.

\section{A REORGANIZAÇÃO DA CLASSE OPERÁRIA}

Mas, se o novo ciclo de prosperidade econômica abriu condições objetivas para o movimento operário e este pôde agir com relativa liberdade em função da crise política interoligárquica, um terceiro elemento ainda se fazia necessário para que a greve geral de junho de 1919 fosse vitoriosa: a organização da classe operária em sindicatos de resistência. N esse sentido, é importante saber quem estava e quem não estava organizado nos sindicatos operários antes da greve geral, quem se organizou no decorrer dela e quem o fez depois.

Até a véspera da greve geral, existiam cerca de dezesseis sindicatos de resistência ativos em Salvador, parte deles fundados ou reorganizados a partir de 1910, enquanto outros haviam sido criados em período anterior e sobrevivido por mais tempo. Durante a paral isação outros três foram fundados e do momento posterior à greve geral até 1921, pel os menos outras catorze organizações sindicais, uma federação, um partido social ista e dois jornais operários foram fundados.

Assim, naquele momento, entre os trabal hadores do complexo portuário deSalvador, foi possível identificar cerca de 8 organizaçõesoperárias atuantes. Entre as mais antigas e importantes, destaca-se a Soci edade U nião dos 0 pe rários Estivadores, fundada no Rio de Janeiro em 13 de setembro de 1903, criando sua sucursal em Salvador no dia 1ํ de maio de 1912, após uma sangrenta luta entre as lideranças dos operários estivadores e os mestres de estiva, que disputavam com o sindicato o controle sobre a gestão do mercado de trabal ho. ${ }^{36}$ Do mesmo período e gravitando em torno da liderança dos estivadores, tínhamos a Soci edade Civil U nião Geral dos Carregadores da Bahia, fundada em 22 deabril de 1912. ${ }^{37}$ Também muito atuante foi a SociedadeU nião 
dos Foguistas, fundada na Capital da República em 26 de setembro de 1903, tendo-se iniciado o processo de organização de sua filial em Salvador em fins de maio de 1910, a partir da mediação de Júlio M arcellino de Carvalho, delegado enviado pela matriz carioca para fundar a sucursal soteropolitana, o que efetivamente ocorreu num domingo, 12 de junho de 1910, com a presença de "numerosa assistência" e dos representantes do chefe de polícia, do governador, do Clube D efensor e Beneficente dos M aquinistas e do Centro O perário da Bahia, além do major Cosme de Farias, eleito orador oficial do sindicato. ${ }^{38} \mathrm{Si}$ tuação semelhante ocorreu com a Associação dos M arinhei ros e Remadores, que havia sido fundada em 23 de outubro de 1904 na Capital da República e, no final de março de 1911, enviou o operário José Francisco de M enezes a Salvador para ali iniciar o processo de organização de uma sucursal, trabalho que foi concluído às 21 horas do dia 3 de abril de 1911, sendo José Bento eleito seu Delegado. ${ }^{39}$ Por fim, tínhamos a Sociedade U nião dos Conferentes da Bahia, fundada em 28 de janeiro de $1918,{ }^{40}$ a sucursal baiana do Grêmio dos M aquinistas da Marinha Civil e a Sociedade dos Calafates, que estava se organizando em março de 1919. ${ }^{41}$

De modo geral, esses sindicatos operários combinavam os tradicionais métodos de ação coletiva, como as greves, com a negociação de suas demandas através de advogados, políticos e autoridades oficiais, fenômeno já verificado também em vários outros estados, a exemplo do Rio de Janeiro, Rio Grande do Sul, M inas Gerais, Pernambuco, Alagoas, M aranhão, Paraíba, Rio Grande do N orte, Ceará, Piauí, Sergipe e Pará. ${ }^{42}$ Isso implica dizer que esse sindicalismo reformista não via a sociedade como al go harmônico, sem conflito de classes, a exemplo de al gumas lideranças de sociedades mutualistas, mas também não era adepto de uma concepção que visse o Estado e seus dirigentes apenas como os fiéis servidores dos interesses dominantes, caso dos libertários. Dependendo da conjuntura, o Estado era, para o conjunto desses sindicatos, um mediador ou mesmo um aliado na luta para obter ganhos, uma posição bastante confortável no peculiar e conflituoso ano de 1919. Havia, pois, uma relação de troca, pela qual o Estado e seus governantes apoiavam algumas das demandas desses operários e de suas organizações, ao passo que estes retribuíam com variadas formas de apoio político que iam desde a modalidade clássica do voto até a simbólica, muitas vezes representada por gestos que indicavam prestígio mútuo das duas partes. ${ }^{43}$ Conclui-se destes dados, também, queo sindicalismo reformista constituiu-senuma clivagem muito mais ampla e enraizada no Brasil que o sindicalismo revolucionário, estabele- 
cido de modo muito sólido em São Paulo, mas que não parece ter sido hegemônico em nenhuma outra região. ${ }^{44}$

Antes da greve geral, haviam sido fundados e permaneciam organizados, também, o Centro Unificador dos Sapateiros, ${ }^{45}$ de 25 de maio de 1906, a Sociedade União D efensora dos Sapateiros, ${ }^{46}$ cujo marco inicial não foi identificado, a Sociedade U nião dos O perários de Padaria, de 6 de abril de $1919,{ }_{1}^{47}$ a Sociedade União dos M etalúrgi cos da Bahia, de 30 de abril de 1919, ${ }^{48}$ o Centro Automobilístico do Estado da Bahia, de 17 de setembro de 1917, ${ }^{49}$ e a Sociedade U nião D efensora dos O perários de Ferrovia, de abril de 1919. ${ }^{50} \mathrm{H}$ avia, ainda, a Soci edade U nião dos M armoristas, de data não identificada, e a mais importante dessas organizações, o Sindicato dos Pedreiros, Carpinteiros e D emais Classes, fundado em 19 de março de 1919, dia de São José, à frente do qual estavam importantes lideranças operárias até 1921, a exemplo de Guilherme Francisco Nery, J osé dos Santos Gomes, Abílio José dos Santos, Antonio Amaro de Sant'Anna e José Domiense da Silva. ${ }^{51}$

A maré de sindicalização parece ter atingido até mesmo alguns setores de trabalhadores não-operários tradicional mente desorganizados e submetidos ao domínio patronal e do Estado, a exemplo dos empregados do comércio e dos servidores públicos, que fundaram a U nião Caixeiral da Bahia em 1ํ de junho de $1919^{52}$ e a Associação dos Funcionários Públicos do Estado da Bahia entre 20 de agosto e 8 de setembro de $1918 .{ }^{53}$

\section{A EXPLOSÃO}

No final de maio de 1919, após uma série de paralisações setoriais ocorridas desde o início do ano, com destaque para a greve nacional dos marítimos, - Sindicato dos Pedreiros, Carpintei ros e D emais Classes desenvolveu uma intensa propaganda na imprensa local, convocando todos os trabalhadores, sem distinção de ofício ou categoria profissional, para que assistissem, em sua sede social, a uma conferência de propaganda sindical a ser proferida no final da tarde de domingo, 1ㅇ de junho de 1919. Em seu apelo, dizia que "o mundo trabalhador já não pode suportar a opressão dos sugadores e detentores do bemestar da humanidade" e convocava a classe operária a "conhecer o caminho por onde vos haveis de libertar das misérias que vos traz o jugo patronal". ${ }^{54}$

0 conferencista era nada menos que Agripino Nazareth, um advogado socialista que havia participado de vários movimentos pelo Brasil afora, entre os quais a Insurreição Anarquista de novembro de 1918 no Rio de Janeiro, 
e que dali em diante exerceu uma indubitável liderança sobre o movimento operário baiano. Ao ser pronunciado e perseguido pelo chefe de polícia carioca, Aurelino Leal, juntamente com dezenas de outros militantes libertários e reformistas, Agripino Nazareth refugiou-se no estado do Espírito Santo e em seguida vei o para Salvador, porto em que só teria conseguido entrar usando nome fal so. ${ }^{55} \mathrm{~A}$ preocupação de Agripino Nazareth não era infundada, poisjá em janeiro de 1919 o chefe de polícia Álvaro Cova oficiara a Gambeta Spínola, inspetor da polícia do porto de Salvador, orientando-o a exercer uma fiscalização mais rígida sobre as embarcações e passagei ros que chegassem e impedindo o desembarque de "elementos indesejáveis e perniciosos". Em sua cruzada contra as chamadas classes perigosas, a autoridade policial fez constar em sua lista os mutilados, incapazes para o trabalho, mendigos, loucos sem acompanhantes, cafetões, ladrões, anarquistas, apaches e passageiros da terceira classe em trânsito, procedentes do Rio da Prata. ${ }^{56}$

A conferência de Agripino Nazareth foi uma faísca sobre um combustível de há muito instável que, na segunda-feira, 2 de junho de 1919, explodiu. Nutrida pelo profundo rancor associado às privações acumuladas ao longo dos anos de guerra, favorecida pela nova fase de prosperidade econômica e pela crise interoligárquica e, finalmente, fortal ecida em sua organização sindical, a classe operária partiu para a ofensiva. Naquele dia, o Sindicato dos Pe dreiros, Carpinteiros e Demais Classes realizou uma assembléia na Praça Rio Branco durante o horário do almoço, momento em que os operários da construção civil assumiram o papel de vanguarda do movimento, paralisando 0 trabal ho nas obras da Biblioteca Pública do Estado, do Palácio do Governo, do Tesouro do Estado e outras construções, portando flâmulas nas quais exigiam "respeito aos seus direitos", aumento salarial de 20 por cento e adoção da jornada de trabalho de oito horas. Depois, realizaram uma passeata pelas ruas do Centro da cidade até a Ladeira da Barra, dando "vivas ao operariado baiano". Em seguida, fizeram o percurso oposto, passando pelo Relógio de São Pedro e Praça Castro Alves, finalizando na sede do sindicato, na rua do Maciel de Cima, quando o número de adesões já chegava a mais de mil. ${ }^{57}$

Dali em diante, o incêndio rapidamente se alastrou, convertendo-se numa greve geral que paralisou toda a cidade, que à época possuía, segundo dados do Censo Demográfico el ndustrial de 1920, 283.422 habitantes, dos quais 45.653 ( 26.955 homens e 18.698 mulheres), ou seja, 16,1 por cento, eram artesãos e operários de oficinas, manufaturas e fábricas e do setor de extração, $3.212(1,1 \%)$ eram trabal hadores dos transportes marítimos efluviais e 5.770 $(2,0 \%)$ eram trabal hadores dos transportes terrestres, perfazendo uma classe 
trabalhadora de 54.635 pessoas, isto é, 19,2 por cento da população soteropolitana. Este número era, contudo, ainda maior, pois não contabilizava a atividade comercial e financeira, que empregava 15.780 (5,6\%) , a administração pública, com 3.406 (1,2\%), a administração particular, com 1.185 (0,5\%) e o sacerdócio e profissões liberais, com 5.932 (2,0\%), setores geralmente tipificados como de classe média, mas que tinham muitos dos seus membros vivendo em situações muito semel hantes ou até inferiores às dos trabalhadores manuais. As estatísticas mostram, ainda, que a classe operária soteropolitana era essencialmente negra e mestiça, posto que a imigração em massa para o Brasil não havia sido canalizada para a Bahia, do que resultou que, em 1920, os estrangeiros eram apenas 10.600 em todo o estado e 7.763 na capital ( principalmente espanhóis e portugueses), dos quais tão-somente 830 eram da classe trabalhadora. ${ }^{58}$

A greve chegou a ser considerada prematura por Agripino Nazareth, lembrando que em sua conferência "tratara apenas de incentivar o movimento associativo, não insinuando, nem ao menos veladamente, uma greve". Argumentava que a principal organização operária no momento da explosão, o Sindicato dos Pedreiros, Carpinteiros e Demais Classes, tinha apenas três meses de vida, contando com um número pequeno de filiados e fundo de greve ainda em formação, impossibilitado, portanto, de auxiliar os grevistas em caso de enfretamento longo com os patrões. Contudo, ao estourar o movimento, o líder social ista ponderou que "a sorte estava lançada" e que "para ver se algo seria possível salvar do naufrágio iminente, um único recurso se impunha: projetar a greve às demais classes proletárias, generalizá-la, para o que na manhã do dia seguinte seria forçoso destinar comissões para todas as casas de trabalho ... para obterem o maior número de solidariedades". ${ }^{59}$ Para atingir tal objetivo, Agripino Nazareth sugeriu que se formassem três comissões operárias, uma com atribuição de negociar com os empreiteiros, outra para buscar apoio às autoridades e a última para tratar com a imprensa. Além disso, uma nova assembléia geral operária foi convocada para o dia seguinte, à tarde, no mesmo local. ${ }^{60}$

Na manhã de 3 de junho, apesar da "chuva intermitente" que caiu durante todo o dia, as comissões formadas na véspera começaram a agir para cumprir as tarefas que Ihes haviam sido designadas. Uma delas rapidamente se transformou numa linha de piquete, rumando para a Cidade Baixa e conseguindo a adesão dos operários de várias construções que ainda se mantinham no trabalho, inclusive das O bras do Porto e da Empresa de Construções Germano de Assis. De lá, os operários voltaram até o Sindicato dos 
Pedreiros, Carpinteiros e D emais C lasses, onde receberam novas adesões e partiram, por volta do meio-dia, para a Península de Itapagipe, ponto de encontro dos demais trabalhadores. Já incorporados os novos companheiros de luta, rumaram todos para a área industrial, onde conseguiram a adesão de milhares de operários, especialmente dos têxteis, o mais importante ramo de produção da época, contando com cerca de 5.624 operários ( 1.840 homens e 3.784 mulheres) segundo o Censo Industrial de 1920. Estavam paralisadas várias fábricas têxteis da Companhia Empório Industrial do Norte, da Companhia Fabril dos Fiais, Companhia União Fabril da Bahia, Companhia Progresso Industrial, Beira-M ar e até mesmo da distante Cia. Valença Industrial. ${ }^{61}$

O enorme setor de vestuário e toucador, calculado pelo Censo Demográfico de 1920 em 22.442 operários ( 6.281 homens e 16.161 mulheres) , também aderiu à greve. As fontes citaram os nomes de al gumas das centenas de ateliês de costura, alfaiatarias, manufaturas de roupas e oficinas de sapateiros aderentes ao movimento, ${ }^{62}$ além das fábricas de cal çados Stella, Gama \& Gama e Trocadero e da Fábrica de Xales Vitória. ${ }^{63} \mathrm{~N}$ o setor fumageiro, a greve atingiu a Fábrica de Charutos Vitória e as fábricas de cigarros Leite \& Alves, A. Guimarães \& Cia., M artins Fernandes e Cruz \& Ruas. O jornal conservador A O rdem chegou a noticiar que esta última empresa teria sido dinamitada pelos grevistas que, em seguida, "percorreram as ruas em atitude ameaçadora", fato não confirmado pelo restante da imprensa. ${ }^{64}$

No setor de alimentação, o movimento conseguiu a adesão de centenas de trabal hadores de padarias e pastelarias e sua Soci edade U nião dos 0 perários de Padaria, que, além da jornada de oito horas por dia, exigiam que seu aumento salarial fosse "em proporção ao trabalho e à força da padaria". Queriam, também, o revezamento noturno e o fim do serviço de entrega de pão. Paralisaram o trabal ho neste setor, também, os filiados da U nião dos A çougueiros e os trabalhadores da Fábrica de M acarrão Progresso. Além disso, ingressaram no movimento os operários da Fábrica M arquesinho, da Fábrica de Cristais Fratelli Vitta, da Serraria Palmeira e das oficinas Belmonte e Cezar Filho. ${ }^{65}$

A greve abarcou também os trabal hadores de toda a infra-estrutura da cidade, a exemplo dos carroceiros, choferes, condutores, motorneiros e demais empregados das companhias Linha Municipal, Linha Circular eTrilhos Centrais, controladoras dos serviços de bondes, elevadores (Lacerda e Taboão), planos inclinados (Gonçalves e Pilar), energia elétrica e iluminação pública (Usinas da Graça e da Preguiça, Gasômetro da Calçada), ferroviários da Compagnie Chemins de Fer, e marítimos da Companhia de Navegação 
Baiana e da Companhia Transportes M arítimos. Até mesmo a Empresa de Asseio da Cidade e o Cemitério Quinta dos Lázaros enfrentaram a rebeldia dos seus empregados, fazendo que o lixo se acumulasse pelas ruas e os cadáveres em estado de putrefação ficassem insepultos. ${ }^{66}$ Para completar, a Guarda N oturna do Comércio ameaçou aderir, abrindo caminho para arrombamentose saques contra propriedades comerciais na Cidade Baixa. ${ }^{67}$

O tamanho e o percurso das passeatas operárias pelas ruas de Salvador são bons indicativos da própria envergadura do movimento. 0 já referido préstito dos trabal hadores da construção civil, realizado nas ruas do Centro em 2 de junho, com mais de mil adesões, cresceu significativamente logo que a ele se incorporaram outras frações da classe operária, alcançando o número de cinco mil trabalhadores. Naquele dia, o número de grevistas já havia sido mensurado entre dez e doze mil operários. Além disso, percebendo que a greve havia ganhado a adesão de várias outras categorias, Agripino Nazareth fez um longo discurso na sede do Sindicato dos Pedreiros e Carpinteiros, propondo a substituição das antigas comissões por um Comitê Central de Greve, com funções análogas às do Comitê de D efesa Proletária criado em São Paulo durante a greve geral de 1917, o que foi aceito. De imediato, o ComitêCentral de Greve redigiu um longo e minucioso memorial dirigido às autoridades e ao patronato, expondo as razões e reivindicações de todas as categorias em greve, além de enviar tel egramas aos senadores Ruy Barbosa e J. J. Seabra, ao deputado reformista M aurício de Lacerda e à União dos O perários em Fábricas de Tecidos e à Associação de Imprensa, ambas do Rio de Janeiro, solicitando apoio e solidariedade a todos. ${ }^{68}$

Em 4 de junho, o movimento já contava 15 mil operários grevistas, atingindo seu ápice no dia 5, quando, além da jornada de trabalho de oito horas por dia, da liberdade de organização sindical e do aumento de salários, os trabalhadores passaram a exigir, também, a isonomia salarial entre homens e mulheres que exercessem as mesmas funções e a abolição do trabalho infantil. Naquele momento, Salvador já era dos operários, com a paralisação do trabalho em todas as oficinas, manufaturas e fábricas, dos transportes urbanos, marítimos, fluviais e ferroviários e dos serviços de geração e distribuição de energia elétrica e iluminação pública..$^{69} \mathrm{O}$ Comitê Central de Greve distribuiu um boletim dirigido aos trabalhadores, aos patrões e à população no qual afirmava que o sol daquele dia iluminaria a "vitória proletária”. Confirmando quea cidade estava totalmente paralisada, os militantes operários convocaram o patronato e os representantes do governador, do chefe de polícia e de todos os jornais da cidade para formularem as bases do acordo. 0 docu- 
mento garantia, ainda, "às autoridades constituídas, às classes conservadoras, aos políticos de to dos os matizes e aos operários em geral que nada nos levará a lisonjear os interesses deste ou daquele partido", posto que "o nosso lema é tudo pelos trabalhadores e só pelos trabalhadores".70

O dia 5 de junho foi marcado, também, por uma intensa e confiante movimentação operária de rua, com piquetes assegurando a continuidade da paralisação do trabalho ou mesmo conseguindo a adesão de um número residual de trabalhadores que ainda se mantinham à margem. Motoristas insistentes tiveram os pneus de seus carros e carroças furados. O súnicos a terem permissão para circular foram os veículos da Assistência Pública e dos agentes de combate à febre amarela, ambos portando bandeiras com uma cruz vermelha. A imprensa vinculada aos interesses dominantes queixou-se de que a falta de energia privava a cidade de iluminação pública e prejudicava os serviços hospitalares e do necrotério..$^{71}$ M esmo o Jornal de N otícias, bastante simpático à causa operária, fez as mesmas ponderações, frisando que “a própria imprensa desprovida de motores particulares" ficaria impedida de circular "na defesa do mesmo operariado". ${ }^{72} \mathrm{~A}$ imprensa oposicionista chegou a dizer quea suspensão do serviço de energia elétrica não agradava ao advogado Agripino Nazareth. ${ }^{73}$

Ainda no dia 5 de junho, ocorreu uma nova passeata. Por volta das 14 horas, os operários começaram a se concentrar em frente à sede do Sindicato dos Pedreiros, Carpinteiros e D emais Classes, no Maciel. De lá, o préstito percorreu as ruas do Centro, passando pela M isericórdia, Praça Rio Branco, Rua Chile, Praça Castro Alves, São Bento, São Pedro, Rua do Cabeça, Praça da Piedade, Largo das M ercês e Rua do Rosário, até chegar ao Palácio da Aclamação, onde a liderança da classe operária entregou uma representação ao governador, e este reafirmou seu "apoio decidido à causa do proletariado". Os dirigentes do Comitê Central de Greve se pronunciaram "aconselhando sempre calma, ordem e respei to à lei" e depois conduziram a multidão operária em torno da Praça Dois de Julho (Campo Grande), onde se encontra o monumento aos heróis da Independência na Bahia, retornando pelo percurso anterior até a Praça Rio Branco numa marcha que contou com 15 mil pessoas. Durante todo o trajeto, palavras de apoio e incentivo foram proferidas por Agripino Nazareth. ${ }^{74}$

Assustados com a dimensão que o movimento havia tomado, os representantes dos interesses capital istas se manifestaram. Em editorial, o D iário da Bahia de 6 de junho disse que as reivindicações operárias eram justas, mas que os trabalhadores precisavam ter a "maior calma e prudência máxima", voltando à sua "faina quotidiana", pois os industriais, seus "fiéis amigos", iriam 
atendê-los naquilo que achassem justo. Na edição do dia 7, o mesmo jornal publicou passagens de um discurso do dr. Mário Leal, um "talentoso e digno professor" da Faculdade de M edicina claramente identificado com a oposição ruísta, no qual ensinava que "o operário não podia e não devia separar-se dos patrões, porquanto tinham os seus interesses estreita eindissoluvel mente ligados" e que "da harmonia das duas forças nasce o progresso, a força e a beleza das nações". Finalizava, apelando para o "espírito ordeiro do povo baiano", pedindo aos operários que não se deixassem enganar pel os que queriam "dourar a popularidade do governo entre as classes trabal hadoras". O s temores dos industriais e comerciantes baianos eram compartilhados até mesmo pelos bancos estrangeiros, que solicitaram garantias ao governo do estado para funcionar, e pelo Cônsul da Noruega, que pediu providências ao general inspetor da região militar "para que o seu automóvel tivesse livre trânsito pelas ruas da cidade".75

A Associação Comercial da Bahia reuniu a sua diretoria no dia 5 e entrou em sessão permanente até o dia 9 de junho, intervalo em que, segundo aqueles empresários, a greve geral adquiriu o caráter de "grande anarquia e subversão da ordem". ${ }^{76}$ Nesse período, os patrões fizeram várias reuniões e trocaram várias cartas com o governador do estado, nas quais pediram "medidas enérgicas e decisivas" para que pudesse ser "restaurada a ordem pública" que havia sido "perturbada por elementos exaltados" que, por meio de piquetes, violavam a "liberdade de trabalho" e aconsel havam o "saque ao comércio", desprotegido em função do suposto recolhimento da polícia pelo governo. Telegramas foram enviados ao juiz federal Paulo Fontes, ao presidente da República Delfim M oreira, à Associação Comercial do Rio de Janeiro e ao Jornal do Comércio, nos quais denunciavam o suposto "maximalismo oficial". A imprensa vinculada à oposição chegou a chamar o chefe do poder executivo estadual de "cabecilha de sedições" e o Palácio da Aclamação de "quartel general da subversão". O s integrantes da polícia foram qualificados como "agitadores ostensivos da anarquia". O governador, por sua vez, retrucava, argumentando que a greve era pacífica, justa elegal, não havendo perturbação da ordem e, portanto, não existindo justificativa para o "emprego de meios violentos". Além disso, dizia estar mediando as negociações com os patrões, conforme lhe pediram uma comissão de operários e seu advogado. ${ }^{77}$

A resistência patronal, porém, foi em vão. Acordos começaram a ser assinados nos setores econômicos mais frágeis ou compostos por empresários menos recalcitrantes, e no dia 9 de junho, segunda-feira, os industriais capitularam. Naquela data, por volta do meio-dia, o Centro Industrial do Algodão divulgou um boletim em nome de suas associadas (Companhia Progresso In- 
dustrial daBahia, CompanhiaEmpório Industrial do Norte, CompanhiaU nião Fabril da Bahia, Companhia Fabril dos Fiais, Companhia Valença Industrial e Fábrica Beira-M ar) no qual concordava em acatar as seguintes reivindicações: 1) jornada de trabalho de oito horas; 2) isonomia salarial entre homens e muIheres que exercessem as mesmas funções; 3) manutenção dos mesmos valores das diárias dos jornaleiros a despei to da diminuição da jornada; 4) aumento de 20 por cento sobre as empreitadas; 5) estabilidade no emprego para os operários que tomaram parte no movimento (considerados pelas companhias e pela associação patronal como não grevistas); 6) reversão de todas as multas para as caixas de beneficência das fábricas e companhias; 7) liberdade de organização para patrões e operários "dentro da legislação vigente". Com o objetivo de desqualificar o papel cumprido pela liderança socialista, os industriais diziam, em seu documento, que os pleitos dos operários já tinham sido "objeto de estudo atento e dedicado" por parte dos seus patrões muito antes do movimento. Outros pontos de "recíproco interesse" ficariam adiados até a promulgação de uma Lei Federal do Trabalho, supostamente "aguardada na vigente legislatura". ${ }^{78}$

O mesmo continuou a ocorrer em outras atividades econômicas, sendo assinados, atéo dia 12 de junho, vários acordos com os pedreiros e carpinteiros, marmoristas, sapateiros, alfaiates, gráficos, padeiros, marítimos, alvarengueiros, estivadores e carregadores, entre outros, prevendo a adoção da jornada de oito horas, a regulamentação do trabal ho infantil e feminino e 0 aumento sal arial. 0 coroamento da vitória ocorreu no dia 15, quando Agripino Nazareth e o ComitêCentral de Greve promoveram um ato público na Praça 15 de Novembro e outra passeata até o Palácio da Aclamação onde foram pronunciadas "vibrantes alocuções" em homenagem ao governador pelos "serviços que foram prestados à causa operária".79

De fato, o governo continuou acenando positivamente para o movimento operário. Em abril de 1919, um projeto de Cosme de Farias e de outros catorze deputados ligados ao PRD já havia sido aprovado na Assembléia Legislativa e sancionado pelo governador sob o número 1.296, estabelecen do o 1 o de M aio como feriado de Estado, fato bastante comemorado pelos sindicatos portuários.$^{80} \mathrm{~N}$ o mês seguinte, outro projeto foi apresentado pelo senador João M artins da Silva e pelo deputado Cosme de Farias, instituindo a jornada de oito horas nos estabelecimentos industriais e oficinas do Estado ou por ele subvencionados, sendo sancionado no dia 10 de junho, em meio às negociações do final da greve geral. ${ }^{81}$ 


\section{DEPOIS DA GREVE GERAL}

Apoiando-nos numa distinção feita por M aria Cecília Velasco e Cruz para a análi se das greves cariocas de $1917,{ }^{82}$ podemos dizer que o movimento operário baiano de 1919 diferenciou-se do de sua fase anterior principalmente por ter superado seu antigo caráter defensivo, quando os operários apenas lutavam em condições adversas para manter conquistas preexistentes, e por ter passado para um movimento ofensivo, apresentando reivindicações novas, distintas em sua própria natureza das de antes. Além disso, o que era apenas um movimento de consumidores tornou-se mais complexo e, sem abandonar a luta contra a carestia, passou a colocar na ordem do dia problemas mais ligados ao mundo do trabalho.

M as a vitória da classe operária não se restringiu ao campo econômico e ao das condições de trabal ho, estendendo-se também à esfera organizativa, até mesmo com a projeção de novas lideranças. Ainda em meio ao turbilhão grevista, alguns sindicatos operários foram criados no âmbito de categorias até então desorganizadas, a exemplo da Sociedade dos 0 ficiais Alfaiates, criada em 5 de junho de 1919 a partir da iniciativa de cem artífices que exigiam jornada de oito horas e aumento de 30 por cento sobre os salários de empreitada, e 20 por cento nas diárias. ${ }^{83}$ Foram organizados, ainda, a Sociedade U nião dos Empregados de Bondes, Luz e Força Elétrica, do dia 6 de junho de $1919,{ }^{84} \mathrm{e}$ 0 Comitê Gráfico de Resistência, ${ }^{85}$ logo convertido na U nião Gráfica Baiana, de 8 de junho de $1919 .{ }^{86}$ A pós a greve geral, foram fundadas a União dos Condutores de Veículos e Classes Anexas da Bahia, de 23 de junho de $1919,{ }_{1}^{87}$ a Sociedade União dos Condutores de Carroças e Classes Anexas, de 23 de julho de $1919,{ }^{88}$ o Sindicato dos M arceneiros, de 8 de julho de 1919, ${ }^{89}$ ea Associação das Costureiras, de dezembro de $1919 .{ }^{90} \mathrm{~N}$ o ano seguinte, foram fundadas a Sociedade Centro e U nião Culinária, de 29 de janeiro de 1920,19 e a Sociedade U nião dos Polidores de Calçados, de 16 de jul ho de $1920 .{ }^{92}$ A mais importante de todas as organizações fundadas após a greve geral foi, no entanto, a Sociedade União Geral dos Tecelões da Bahia, instituída em 21 de agosto de 1919 em conflito aberto contra os poderosos capitães da indústria têxtil e seu Centro Industrial do Algodão. ${ }^{93} \mathrm{~A}$ despeito da pressão patronal e de suas sociedades beneficentes, o processo de organização sindical também atingiu o Recôncavo Fumageiro, sendo fundados o Comitê de D efesa O perária, na vila de M uritiba em 1 o de agosto de 1919, ${ }^{44}$ e a Sociedade de Resistência Protetora dos O perários de São Félix e Cachoeira, de abril de 1920. ${ }^{95}$ Uma certa União dos Pedreiros Nazarenos, sucursal do Sindicato dos Pedreiros e Carpinteiros, foi fundada na cidade de Nazaré no final de agosto de $1919 .{ }^{96}$ A té mesmo na I lha de M aré, 
um Sindicato de O fícios Vários foi fundado em janeiro de 1921 a partir da intervenção direta deAgripino Nazareth. ${ }^{97}$

O ápice do processo de crescimento e fortal ecimento da estrutura sindical ocorreu com a convocação do Primeiro Congresso dos Trabalhadores Baianos, real izado entre 14 e 20 de julho de 1919, ${ }^{98}$ e com a fundação da Federação dos Trabalhadores Baianos, em 13 de fevereiro de 1920. ${ }^{99}$ Tanto o congresso quanto a federação foram hegemonizados, desde o início, pelas correntes sindicais reformistas ligadas ao grupo socialista liderado por Agripino Nazareth. O Sindicato dos Pedreiros e Carpinteiros, que havia se destacado como organização dirigente da greve geral e do qual Agripino era advogado, mais uma vez cumpriu um papel de vanguarda na organização do mencionado conclave e de seu fruto mais primoroso. Durante os sete dias em que se reuniu, desde a abertura, no Teatro São João, o Primeiro Congresso dos Trabal hadores Baianos agregou dez sindicatos e 26 delegados entre ferroviários, sapateiros, pedreiros, carpinteiros, marmoristas, marceneiros, padeiros, gráficos, operários das linhas de bonde e usinas de energia e carroceiros. As discussões giraram em torno do socialismo coletivista e do internacionalismo, da substituição das sociedades mutualistas por sociedades de resistência sem a presença de mestres e contramestres, da abolição do trabalho de menores de catorze anos, da regulamentação do trabalho feminino e da instituição do salário mínimo. Seu ideário social ainda tinha por referência a Revolução Francesa, sendo a Tomada da Bastilha em 14 de julho de 1789 apresentada como merecedora de ser comemorada pelos operários "com o mais intenso júbilo", posto que teria assinalado a "vitória do socialismo". ${ }^{100}$ Ainda mais importante de se observar foi a presença de representantes de "todas as classes da sociedade, inclusive das autoridades civis, militares e do Estado" ea ausência das organizações sindicais do complexo marítimo e portuário, demarcando uma clivagem que reproduz uma separação existente no movimento sindical carioca. Quanto à Federação dos Trabal hadores Baianos, em julho de 1920, com apenas seis meses de criada, ela já aglutinava dezesseis sindicatos e mais de 25 mil trabalhadores. Em 24 de setembro de 1920, porém, a FTB sofreu uma importante cisão à esquerda representada pelo Sindicato dos Pedrei ros e Carpinteiros, que havia aderido a uma variante do sindicalismo revolucionário após o Tercei ro Congresso O perário Brasileiro, quando os operários Gaudêncio José dos Santos e Annibal Lopes Pinho representaram catorze sindicatos filiados naquela ocasião. ${ }^{101}$

As correntes reformistas, todavia, não perderam força, continuando a manter a hegemonia sobre o movimento operário da época. Agripino Nazareth já havia fundado um certo Partido Socialista Baiano em agosto de 1920, 
com sólida base operária. Em seu programa político, relativamente avançado para a época, constavam os seguintes pontos: socialização do comércio, das grandes indústrias e de todos os meios de transportes; fixação do salário mínimo; equiparação dos operários municipais, estaduais e federais aos funcionários públicos para efeito de obtenção das vantagens relativas ao montepio recebido pelos quadros estáveis do serviço público; abolição de todos os impostos indiretos e transformação dos diretos num imposto progressivo sobre qualquer renda superior a seis contos de réis anuais; voto da mulher e do soldado; reforma das leis de inquilinato e despejo. Além disso, moções de simpatia aos trabal hadores de to do o mundo e de protesto contra a hostilidade do governo francês em relação à Rússia revolucionária foram aprovadas. Por fim, foram lançadas as candidaturas de M aurício de Lacerda ao Senado, e de Agripino Nazareth à Câmara Federal, na sede da Sociedade U nião dos Carregadores das D ocas, ocasião em que Agripino proferiu uma Conferência sobrea questão social e os partidos socialistas. ${ }^{102}$

A maior politização do movimento operário baiano pode ser vista, também, nas questões raciais, com o Sindicato dos M arceneiros promovendo, em agosto de 1919, um "comício de protesto contra as chacinas de homens de cor ultimamente perpetradas em Chicago", evento para o qual foram chamadas "todas as laboriosas classes" para que juntas pudessem repelir "todos os preconceitos inconfessáveis de raça ainda existentes na América do Norte". ${ }^{103} \mathrm{~A}$ manifestação constitui-se numa forte evidência do quanto a liderança socialista baiana estava informada acerca das questões internacionais daquele ano, posto que o fim da Primeira Guerra Mundial havia sido marcado por um intenso movimento migratório nos Estados Unidos, com as populações negras saindo do campo para cidades como Pittsburgh, Cleveland e Chicago em busca de emprego e melhores condições de vida, mas efetivamente tendo de enfrentar as ações criminosas da Ku K Iux Klan. ${ }^{104}$ Paradoxalmente, a manifestação demonstrava, também, uma aparenteignorância dos social istas em rel ação aos preconceitos raciais (e sociais) existentes em seu próprio país de modo geral e na Bahia em particular.

A delimitação político-ideológica posterior à greve geral fica clara também pelo surgimento da nova imprensa operária, em especial do socialista Germinal, editado por Agripino Nazareth entre março e maio de 1920, e do sindicalista revolucionário A Voz do Trabalhador, jornal publicado pelo Sindicato dos Pedreiros e Carpinteiros entre outubro de 1920 e outubro de $1922 .{ }^{105}$ Além disso, novas greves tiveram de ser feitas, destacando-se a radical mobilização dos têxteis, durante quase todo o mês de setembro de 1919, ${ }^{106}$ e o vitorioso movimento da construção civil de fevereiro-março de 1920 após 58 
dias de luta contra os empreiteiros. ${ }^{107} \mathrm{~A}$ greve geral de Salvador terminou por se expandir e atingir várias cidades do Recôncavo, como Nazaré, Cachoeira, São Félix e a vila de M uritiba, locais onde os operários se levantaram também por aumentos salariais e pela jornada de oito horas de trabal ho ainda em junho de 1919. ${ }^{108}$ Por fim, é preciso dizer que não apenas a solidariedade e a consciência de classe floresceram entre 1919 e 1921, já que conflitos e cisões sindicais ocorreram entre os marceneiros, padeiros, estivadores, carregadores e foguistas. ${ }^{109}$ Além disso, as greves de princípios de 1921 no porto e no ramo têxtil marcaram um momento de derrota operária e de inflexão no comportamento do Estado, pois os patrões aproveitaram-se das rivalidades já mencionadas e usaram os carregadores de trapiches como fura-greves do movimento dos carregadores das docas, ao passo que as autoridades passaram a reprimir duramente as lideranças operárias, prendendo o marceneiro José Domiense da Silva, presidente da Federação dos Trabalhadores Baianos, e deportando Agripino N azareth, que chegou a ser ameaçado de desterro para o Amazonas ou M ato Grosso, mas efetivamente desembarcou no Rio de Janeiro, onde enfrentaria fortes embates com o PCB na década de 1920 e trilharia seu caminho até o governo de Getúlio Vargas. É que a partir de 1930, quando foi iniciado o processo de organização do M inistério do Trabalho, Indústria e Comércio, Lindolfo Collor, titular da pasta, cercou-se de antigos líderes reformistas da classe operária, a exemplo dos advogados Agripino N azareth, Evaristo de Moraes e Joaquim Pimenta, do jornalista Carlos Cavaco e do deputado federal Deodato $\mathrm{M}$ aia, convertendo-os em técnicos e assessores diretos do referido órgão. ${ }^{110} \mathrm{M}$ as estas são outras histórias...

\section{NOTAS}

${ }^{1} O$ presente artigo resume, parcialmente, al guns dos resultados de pesquisa contidos em minha dissertação de mestrado defen dida em 2001 sob a competente e séria orientação da professora M aria Cecília Vel asco e Cruz. Agradeço a ela e a Carlos Zacarias F. de Sena Jr., pelas valiosas sugestões feitas ao presente texto. Sou grato pela bolsa de pesquisa que recebi do CN Pq entre 1999 e 2001 e pelo apoio do PPGH -UFBA para a realização de pesquisas no Arquivo Edgard Leuenroth (AEL-Unicamp). Contatos: aascastellucci@uol.com.br.

${ }^{2}$ Ver tabelas de greves e grevistas em FERRO, M. História da Primeira Guerra M undial, 1914-1918. Tradução de Stella Lourenço. Lisboa: Edições 70, 1992, p.261-2.

${ }^{3}$ Ver: FAUSTO, B. Conflito social na república oligárquica: a greve geral de 1917. Estudos Cebrap, São Paulo, n.10, p.79-109, out.-dez. 1974, eTrabalho urbano e conflito social (18901920). São Paulo/Rio de Janeiro: Difel, 1976; CAM POS, C. H. O sonhar libertário: movi- 
mento operário nos anos 1917-1921. Campinas (SP): Pontes/Ed. Unicamp, 1998; LOPREATO, Ch. R. 0 Espírito da revolta: a greve geral anarquista. São Paulo: Annablume, 2000.

${ }^{4}$ VELASCO E CRUZ, M . C. Amarelo enegro: matizes do comportamento operário na República Velha. 1981. Dissertação (M estrado em Ciência Política) - luperj, Rio de Janeiro, 1981.

${ }^{5}$ PETERSEN , S. R. F. “Quea união operária seja a nossa pátria!": história das lutas dos ope rários gaúchos para construir suas organizações. Santa M aria: Ed. U FSM ; Porto Alegre: Ed. UFRGS, 2001, principalmente o capítulo 5.

${ }^{6}$ LONER, B. A. Construção de classe: operários de Pelotas e Rio Grande (1888-1930). Pelotas: Ed. UFPel., 2001, principalmente o capítulo 6.

${ }^{7}$ ADDOR, C. A. A Insurreição Anarquista no Rio de Janeiro. Rio de Janeiro: Dois Pontos, 1986.

${ }^{8}$ REZEN DE, A. P. de M . A classe operária em Pernambuco: cooptação e resistência (19001922). 1981. Dissertação (M estrado em História) - IFCH, Unicamp, Campinas, 1981, p.88-114.

${ }^{9}$ Sobre 0 assunto, ver: PETERSEN, S. R. F. Cruzando fronteiras: as pesquisas regionais e a história operária brasileira. In: ARAÚ J O, A. M . C. (org.) Trabalho, cultura e cidadania: um balanço da história social brasileira. São Paulo: Scritta, 1997, p.85-103.

${ }^{10}$ RUBI M , A. A . C. M ovimentos sociais e meios de comunicação - Bahia, 1917-1921. Cadernos do CEAS, Salvador, n.61, p.30-43, maio/jul. 1979; RUBIM , A. A. C. \& RUBIM , J. L. C. As lutas operárias na Bahia (1917-1921). Cadernos do CEAS, Salvador, n.80, p.22-34, jul./ago. 1982.

${ }^{11}$ FON TES, J. R. M anifestações operárias na Bahia: o movimento grevista, 1888-1930. Dissertação (M estrado em Ciências Sociais) - FFCH, UFBA, Salvador, 1988.

${ }^{12}$ SANTOS, M . A. da S. Sobrevivência etensões: Salvador, 1890-1930. 1982. Tese (D outorado em História) - FFLCH, USP, São Paulo, 1982. Uma versão do trabalho foi publicada recentemente. Ver: SANTOS, M . A. S. A República do povo: sobrevivência e tensão - Salvador, 1890-1930. Salvador: Ed. UFBA, 2001.

${ }^{13}$ CASTELLU CCI, A. A. S. Industriais e operários baianos numa conjuntura de crise (19141921). Salvador: Fieb, 2004 (II Prêmio Fieb de Economia Industrial), p.95-145, eSANTOS, M. A. S. A República do povo, cit., p.147-86.

${ }^{14}$ Sobre o debate acerca do impacto da guerra no processo de industrialização, ver: SUZIGAN, W. Indústria Brasileira: origens e desenvolvimento. São Paulo: Hucitec; Campinas (SP): Ed. Unicamp, 2000.

${ }^{15}$ Relatórios da Companhia Empório Industrial do Norte dos anos de 1912 a 1921, publicados nos seguintes jornais: A Tarde, 29.03.1913; Diário da Bahia, 21.06.1914; J ornal de N otícias, 03.04.1915; Diário O ficial do Estado da Bahia, 31.03.1916; 02.04.1918; 29.03.1919; 31.03.1920; Relatório da Direção da Companhia Empório Industrial do N orte e Parecer do Conselho Fiscal apresentados aos srs. Acionistas na Sessão da Assembléia Geral O rdinária de 2 de abril de 1918. Bahia: Reis \& Companhia, 1918. 
${ }^{16}$ Relatórios da Direção da Companhia Progresso Industrial da Bahia dos anos de 1912 a 1920 publicados no Diário O ficial do Estado da Bahia das seguintes edições: 14.03.1916; 25.03.1917; 27.03.1918; 28.03.1919; 28.04.1920; 29.03.1921.

${ }^{17}$ Relatórios da Companhia Valença Industrial dos anos de 1912 a 1920 publicados nos seguintes jornais: Jornal de N otícias, 29.04.1913; 27.04.1915; Diário O ficial do Estado da Bahia, 26.03.1916; 28.03.1917; 27.03.1918; 14.03.1919; 21.03.1920; 20.03.1921.

${ }^{18}$ Relatórios da Companhia Fabril dos Fiais dos anos de 1912 a 1920 publicados no Diário da Bahia, 25.02.1913 e no Diário Oficial da Bahia, 24.02.1916; 24.02.1917; 21.02.1918; 20.02.1919; 22.02.1920; 19.02.1921.

${ }^{19}$ Relatórios da Companhia União Fabril da Bahia publicados nos seguintes jornais: Diário da Bahia, 24.02.1915; Diário Oficial do Estado da Bahia, 23.04.1916; 09.04.1918; 25.03.1919; 28.04.1920; 27.03.1921.

20 APEB, Seção Republicana, D ocumentação da Secretaria da Agricultura, Indústria e Comércio. Relatório dos Serviços da Secretária da Agricultura, Indústria, Comércio, Viação e O bras Públicas durante o ano de 1920. Caixa 2386, M aço 178, Doc. 746; Diário O ficial do Estado da Bahia - Edição Especial do Centenário da Independência da Bahia, 02.07.1923, p.157-8 e 274-6; Anuário Estatístico da Bahia do ano de 1923. Bahia: Imprensa O ficial do Estado, 1924; Relatórios da Companhia Empório Industrial do Norte dos anos de 1912 a 1921 publicados nos seguintes jornais: A Tarde, 29.03.1913; Diário da Bahia, 21.06.1914; Jornal de N otícias, 03.04.1915; Diário O ficial do Estado da Bahia, 31.03.1916; 02.04.1918; 29.03.1919; 31.03.1920; Relatório da Direção da Companhia Empório Industrial do N orte e Parecer do Consel ho Fiscal apresentados aos srs. Acionistas na Sessão da Assembléia Geral Ordinária de 2 de abril de 1918. Bahia: Reis \& Companhia, 1918; Relatórios da Direção da Companhia Progresso Industrial da Bahia dos anos de 1912 a 1920 publicados no Diário Oficial do Estado da Bahia das seguintes edições: 14.03.1916; 25.03.1917; 27.03.1918; 28.03.1919; 28.04.1920; 29.03.1921; Relatórios da Companhia Valença Industrial dos anos de 1912 a 1920 publicados nos seguintes jornais: Jornal de Notícias, 29.04.1913; 27.04.1915; Diário Oficial do Estado da Bahia, 26.03.1916; 28.03.1917; 27.03.1918; 14.03.1919; 21.03.1920; 20.03.1921; Relatórios da Companhia Fabril dos Fiais dos anos de 1912 a 1920 publicados nos seguintes jornais: Diário da Bahia, 25.02.1913; Diário O ficial do Estado da Bahia, 24.02.1916; 24.02.1917; 21.02.1918; 20.02.1919; 22.02.1920; 19.02.1921; Relatórios da Companhia União Fabril da Bahia publicados nos seguintes jornais: Diário da Bahia, 24.02.1915; Diário Oficial do Estado da Bahia, 23.04.1916; 09.04.1918; 25.03.1919; 28.04.1920; 27.03.1921.

${ }^{21} 0$ Tempo, 23.07.1918, p.1.

${ }^{22} 0$ Tempo, 11 e 12.11.1918, eA Tarde, 20.12.1918, p.1; Relatório CEIN . Diário O ficial da Bahia, 31.03.1920.

${ }^{23}$ A Tarde, 19 e 20.01.1917, p.1 e p.1 e 3, respectivamente.

${ }^{24}$ Diário O ficial do Estado da Bahia, 20.02.1919.

${ }^{25}$ Jornal de N otícias, 11.01.1920, p.1.

${ }^{26}$ A ta da Sessão de Assembléia Geral Extraordinária dos Srs. Acionistas da Companhia Cha- 
pelaria N orte Industrial Realizada em 22 de setembro de 1919. Diário O ficial do Estado da Bahia, 11.10.1919.

${ }^{27}$ A Voz do Trabalhador, Salvador, n.22, 05.03.1921, p.1-2.

${ }^{28}$ Sobre as reformas urbanas, ver: LEITE, R. C. N . E a Bahia civiliza-se... Idéias de civilização e cenas de anti-civilidade em um contexto de modernização urbana. Salvador, 19121916. Dissertação (M estrado em H istória) - FFCH, UFBA, Salvador, 1996; SANTOS, M . A. S. Sobrevivência e tensões, p.56-68; PIN H EIRO, E. P. Europa, França e Bahia: difusão e adaptação de modelos urbanos (Paris, Rio e Salvador). Salvador: Ed. U FBA, 2002.

${ }^{29}$ UBATU BA, E. $O$ Estado da Bahia: Bahia Urbana - Bahia Rural (Conferência Realizada Pelo Dr. Ezequiel U batuba no Salão N obre do IGH BA em setembro de 1917). Bahia: Imprensa Oficial, 1918, p.19-20.

${ }^{30} \mathrm{M}$ ensagem Apresentada à Assembléia Geral Legislativa do Estado da Bahia na Abertura da 2a Sessão O rdinária da 12a Legislatura Pelo Dr. J. J. Seabra, Governador do Estado. Bahia: Seção de O bras da "Revista do Brasil", 1914, p.71-4; M ensagem A presentada à Assembléia Geral Legislativa do Estado da Bahia na Abertura da 1ª Sessão O rdinária da 13a Legislatura Pelo Dr. J. J. Seabra, Governador do Estado. Bahia: Seção de O bras da "Revista do Brasil", 1915, p.105-13.

${ }^{31}$ Sobre a estrutura do setor da construção civil, ver: SI LVA, F. T. da. Operários sem patrões: os trabal hadores da cidade de Santos no entreguerras. Campinas (SP): Ed. Unicamp, 2003, capítulos 1 e 2.

${ }^{32}$ Sobre o assunto, ver: SAM PAIO, C. N . Partidos Políticos da Bahia na Primeira República: uma política de acomodação. 2.ed. Salvador: Ed. UFBA, 1999.

${ }_{33}$ SO UZA, M . do C. C. de. 0 processo político-partidário na República Velha. In: M OTTA, C. G. (Org.) Brasil em perspectiva. 2.ed. São Paulo: Difel, 1969.

${ }^{34}$ SAM PAIO, C. N. Partidos Políticos..., cit., p.135-42; 146-57; PAN G, E.-S. Coronelismo e oligarquias (1889-1934) . A Bahia na Primeira República. Rio de Janeiro: Civilização Brasileira, 1979, p.134-40.

${ }^{35}$ BAK, J. Labor, community, and the making of a cross-class alliance in Brazil: the 1917 railroad strikes in Rio Grande do Sul. Hispanic American Historical Review. Carolina do Norte, EUA: Duke University Press, v.78, n.2, p.179-227, 1998. Ver também: LONER, B. A. 0 canto da sereia: os operários gaú chos e a oposição na República Velha. H istória-U nisinos. São Leopoldo (RS): PPGH-Unisinos, v.6, n.6, p.97-125, 2002; SI LVA JR., A. L. da. A bipolaridade política rio-grandense e o movimento operário (188?-1925). Estudos I beroAmericanos. Porto Alegre: PUCRS, v.XXII, n.2, p.5-26, dez. 1996.

${ }^{36}$ Ver VELASCO E CRUZ, M. C. Virando o jogo: estivadores ecarregadores no Rio de Janeiro da Primeira República. Tese (D outorado em Sociologia) - FFLCH, USP, São Paulo, 1998, e SolidariedadeX rivalidade: a formação do sindicalismo estivador brasileiro. História Unisinos, São Leopoldo (RS): PPGH-Unisinos, v.6, n.6, p.29-62, 2002.

${ }^{37}$ Estatutos da Sociedade Civil União Geral dos Carregadores da Bahia. Diário 0 ficial da Bahia, 12.09.1920.

${ }^{38}$ Estatutos da S. União dos Foguistas. Diário Oficial do Estado da Bahia, 22.05.1919; 0 
Tempo, 21.11.1918, p.4; Diário de Notícias, 04 e 11.06.1910, p.1 e 3; 25.05.1910, p.5; 13.06.1910, p.5. Os organizadores da S. União dos Foguistas na Bahia eram João Fausto Góes, Rogaciano Carteado da Silva e M anoel Augusto Vieira.

${ }^{39}$ Diário de N otícias, 28.03.1911; 01, 03 e 04.04.1911, p.2.

${ }^{40}$ Estatutos da Sociedade União dos Conferentes da Bahia. Diário O ficial do Estado da Bahia, 04.07.1920.

${ }^{41}$ Diário de Notícias, 07.03.1919, p.2.

${ }^{42}$ Ver os já citados trabalhos de M aria Cecília Velasco e Cruz, além do artigo da mesma autora: Tradições negras na formação de um sindicato: Sociedade de Resistência dos TrabaIhadores em Trapiche e Café. Rio de Janeiro, 1905-1930. Afro-Ásia, Salvador: Ceao-UFBA, n.24, p.243-90, 2000; BATALH A, C. H. M. Uma outra consciência de classe? 0 sindicalismo reformista na Primeira República. Ciências Sociais H oje, São Paulo: Vértice/Anpocs, p.117-27, 1990; BATALH A, C. H. M 0 movimento operário na Primeira República. Rio de Janeiro: Jorge Zahar, 2000, p.31-5; GOM ES, A. de C. A invenção do trabalhismo. 2.ed. Rio de Janeiro: Relume-Dumará, 1994; BILH ÃO, I. Rivalidades e solidariedades no movimento operário (Porto Alegre, 1906-1911). Porto Alegre: Ed. PU CRS, 1999; DUTRA, E. F. Caminhos operários nas M inas Gerais: um estudo das práticas operárias em Juiz de Fora e Belo Horizonte na Primeira República. São Paulo: Hucitec/Ed. UFM G, 1988; ANDRADE, S. M . B. V. Classe operária em Juiz de Fora: uma história de lutas (1912-1924). Juiz de Fora: Ed. UFJF, 1987; HARDM AN , F. F. \& LEONARD, V. H istória da indústria e do trabalho no Brasil (das origens aos anos 20). 2.ed. revista e ampliada. São Paulo: Ática, 1991; SALLES, V. M arxismo, socialismo e os militantes excluídos: capítulos de história do Pará. Belém: PakaTatu, 2001.

${ }^{43}$ Por ocasião das eleições legislativas de janeiro de 1919, por exemplo, um manifesto assinado por vários comerciantes e caixei ros e por diversos diretores da U nião dos 0 perários Estivadores, União dos Carregadores, União dos Conferentes e U nião dos Foguistas, foi dirigido ao comércio e às classes operárias, conclamando-os a sufragarem os candidatos do PRD. Na noite de 9 de março de 1919, uma grande passeata operária, organizada pelos dirigentes da União dos 0 perários Estivadores, União dos Carregadores, U nião dos Foguistas, União dos Conferentes e Associação dos M arinheiros e Remadores, percorreu as ruas do Centro de Salvador e em seguida postou-se em frenteà residência do senador J. J. Seabra para anunciar seu apoio à candidatura de Epitácio Pessoa à presidência da República, conforme desejo do PRD. Em resposta, Seabra falou da al egria que sentia por receber "o apoio e o conforto dos operários" e "referiu-se à urgência de ser decretado o Código do Trabalho, em que os direitos do operariado fiquem bem discriminados e garantidos, impedindo assim que nos choques entre o trabal ho e o capital, este sobrepuje aquele, asfixiando as suas aspirações, sempre modestas e justas". Ao final de maio de 1919, uma multidão operária foi conduzida pela Associação dos M arinheiros e Remadores atéo Palácio da Aclamação para prestar homenagem ao governador Antonio Ferrão M oniz deAragão que estava aniversariando e ao mesmo tempo agradecer-Ihe o apoio dado durante a greve nacional dos marítimos. Finalmente, em outubro de 1919, os dirigentes da U nião dos 0 perários Estivadores encabeçaram mais uma iniciativa, que contou com o apoio da U nião dos Carregadores das Docas e Trapiches, da U nião dos Foguistas M arítimos eTerrestres e da Associação dos M ari- 
nheiros e Remadores objetivando apoiar a candidatura do próprio José Joaquim Seabra em sua campanha para suceder Antônio Ferrão M oniz deAragão no governo do estado, apoio referendado numa assembléia conjunta destas organizações que contou com cinco mil operários. Ver: Jornal deN otícias, 09.01.1919, p.2; 0 D emocrata, 09.01.1919, p.1 e11.03.1919, p.1; 0 Tempo, 09.01.1919, p.1; 31.05.1919, p.1-2; 21.10.1919, p.1.

${ }^{44}$ Sobre o anarquismo e o sindicalismo revolucionário, ver: TOLEDO, E. T. 0 sindicalismo revolucionário ea Federação O perária de São Paulo no início do século XX. Cadernos de H istória Social, Campinas (SP), n.2, p.27-41, 1995; . Em torno do jornal O Amigo do Povo: os grupos de afinidade e a propaganda anarquista em São Paulo nos primeiros anos deste século. Cadernos AEL, Campinas (SP): AEL, n.8/9, p.89-116, 1998; 0 sindicalismo revolucionário em São Paulo e na I tália: circulação de idéias e experiências na militância sindical transnacional entre 1890 e o fascismo. Campinas, 2002. Tese (D outorado em História) - IFCH, Unicamp, 2002.

${ }^{45}$ Diário de Notícias, 26.05.1906, p.2.

${ }^{46}$ Em princípios de 1920, o Centro Unificador dos Sapateiros, fundado em 25.05.1906, dissolveu-se e transferiu seus filiados e patrimônio para a Sociedade União Defensora dos Sapateiros. Germinal, Salvador, n.1, 19.03.1920, p.11; Germinal, Salvador, n.2, 03.04.1920, p.6.

${ }^{47}$ Estatutos da Sociedade União dos O perários de Padaria. Diário Oficial do Estado da Bahia, 12.09.1919.

${ }^{48}$ Estatutos da Sociedade União dos M etalúrgicos da Bahia. Diário O ficial do Estado da Bahia, 14.10.1919.

${ }^{49}$ Estatutos do Centro Automobilístico do Estado da Bahia. Diário O ficial do Estado da Bahia, 24.04.1920.

${ }^{50}$ Estatutos da Sociedade U nião D efensora dos Operários de Ferrovia. Diário O ficial da Bahia, 18.03.1920.

${ }^{51}$ Estatutos do Sindicato dos Pedreiros, Carpinteiros e Demais Classes. Diário O ficial da Bahia, 19.10.1919.

${ }^{52}$ Estatutos da União Caixeiral da Bahia. Diário O ficial do Estado da Bahia, 11.07.1920.

${ }^{53}$ Projeto de Estatutos da Associação dos Funcionários Públicos do Estado da Bahia. Diário O ficial do Estado da Bahia, 31.07.1918; Projeto de Estatutos da Associação dos Funcionários Públicos do Estado da Bahia (Redigido de acordo com as emendas). Diário O ficial do Estado da Bahia, 15.08.1918; 0 Tempo, 17 e19.07.1918; 8, 21 e27.08.1918; 5, 6 e9.09.1918.

${ }^{54}$ O Tempo, 31.05.1919, p.1-2; O Imparcial, 31.05.1919, p.2; Diário da Bahia, 01.06.1919, p.2.

${ }_{55}$ "Ao Povo Baiano", artigo assinado por Agripino Nazareth no Jornal deN otícias, 15.06.1919, p.3 e 5 .

${ }^{56}$ Jornal de Notícias, 23.01.1919, p.2; 0 Democrata, 23.01.1919, p.2.

${ }^{57}$ Diário de Notícias, 03.06.1919, p.1; Diário da Bahia, 03.06.1919, p.1; Jornal de Notícias, 03.06.1919, p.3. 
${ }^{58}$ Recenseamento do Brasil realizado em 10 de setembro de 1920. v. IV (1a Parte - População), p.52-3, 308-11, 598-601, (2 2- Parte - População), p.6, (5a Parte - População), p.362-

3 , v. V (1 1 a Parte - Indústria), p.252-77. Remeta-se a esta nota todas as vezes que fizermos referência aos Censos de 1920.

${ }^{59} \mathrm{O}$ Protesto do O perariado. A Conferência do Dr. Agripino Nazareth no Sindicato dos Pedreiros e Carpinteiros. 0 Tempo, edições dos dias 6, 8, 9, 10 e 11.12.1919.

${ }^{60}$ Diário da Bahia, Diário de N otícias e 0 Imparcial, 03.06.1919, p.1.

${ }^{61}$ Diário de N otícias, 04 e 05.06.1919, p.1-2; Diário da Bahia, 04 e 05.06.1919, p.1; Jornal de N otícias, 05.06.1919, p.3; 0 Democrata, 05.06.1919, p.1; A Tarde, 04.06.1919, p.1.

${ }^{62}$ Diário da Bahia, 07.06.1919, p.1; 0 Tempo, 07.06.1919, p.1.

${ }^{63}$ Diário de N oticias, 04 e 05.06.1919, p.1-2; Diário da Bahia, 04 e 05.06.1919, p.1; Jornal de Notícias, 05.06.1919, p.3.

${ }^{64}$ D iário de N oticias, 04.06.1919, p.1-2; Diário da Bahia, 04.06.1919, eA O rdem, 07.06.1919, p.1.

${ }^{65}$ Diário de N oticias, 04 e 05.06.1919, p.1-2; Diário da Bahia, 04, 05 e 06.06.1919, p.1; Jornal de Notícias, 05.06.1919, p.3; 0 Tempo, 05 e 06.06.1919, p.1; A Tarde, 04.06.1919, p.1.

${ }^{66}$ Diário da Bahia, 07.06.1919, p.1.

${ }^{67}$ Jornal de N otícias, 05.06.1919, p.3; D iário de N otícias, 05.06.1919, p.1-2; Diário da Bahia, 05.06.1919, p.1.

${ }^{68}$ Diário de N otícias, 04 e 05.06.1919, p.1-2; Diário da Bahia, 04 e 05.06.1919, p.1; Jornal de Notícias, 05.06.1919, p.3; A Tarde, 04.06.1919, p.1.

${ }^{69}$ Diário deN otícias, Diário da Bahia, Jornal deN otícias, 0 Democrata eO Tempo, 05.06.1919, p.1-2, 1, 3, 1 e 1, respectivamente.

70 "Aos Trabalhadores! Aos Patrões! À População Baiana". Boletim do Comitê Central de Greve de 05.06.1919 publicado no jornal O Tempo, 06.06.1919, p.1, eno Diário da Bahia, 06.06.1919, p.1.

${ }^{71}$ Diário da Bahia, 05 e 06.06.1919, p.1; Diário de N otícias, 05.06.1919, p.1-2.

${ }^{72}$ Jornal de Notícias, 05.06.1919, p.3.

${ }^{73}$ Diário da Bahia, 06.06.1919, p.1.

${ }^{74}$ O Tempo e Diário da Bahia, 06.06.1919, p.1.

${ }^{75}$ Diário da Bahia, 06 e 07.06.1919, p.1; 0 Tempo, 07.06.1919, p.1.

${ }^{76}$ Livro de Atas da Associação Comercial da Bahia (1917-1921), 2a Sessão Ordinária e Continuada da Diretoria da ACB, 05 a 09.06.1919, p.164-6.

${ }^{17}$ Diário da Bahia, 06 e 11.06.1919; 0 Tempo, 07.06.1919, p.1; Diário de Notícias, 10.06.1919, p.1; Relatório da Diretoria da Associação Comercial da Bahia, Apresentado e A provado em Reunião da Assembléia Geral O rdinária de 23 de M arço de 1920. Salvador: Oficinas da Livraria Duas Américas, 1920, p.91-109. ARAGÃO, A. F. M . de. A Bahia e os seus Governadores na República. Bahia: Imprensa O ficial do Estado, 1923, p.655-60. 
${ }^{78}$ Boletim do Centro Industrial do Algodão. Diário O ficial do Estado da Bahia e O Tempo, 10.06.1919, p.1.

${ }^{79}$ Jornal de Notícias, 17.06.1919, p.3.

${ }^{80}$ APEB, Seção Legislativa, livros 59, 116, 908, 954, 1102; jornais 0 Tempo, 02.05.1919, p.12; 0 Democrata, 01 e 02.05.1919, p.1 e 2, respectivamente; Jornal de N otícias, 03.05.1919, p.2; A Tarde, 02.05.1919, p.2.

${ }^{81}$ APEB, Seção Legislativa, livros 59, 116, 908, 1102 e 1200; 0 Tempo, 08.05.1919; 05, 06 e 18.06.1919; Diário Oficial do Estado da Bahia, 18.06.1919.

${ }^{82}$ VELASCO E CRUZ, M. C. Amarelo e negro, p.122-3.

${ }^{83}$ Diário da Bahia, 05.06.1919, p.1-2; 0 Tempo, 05.06.1919, p.1.

${ }^{84}$ Estatutos da Sociedade União dos Empregados de Bondes, Luz e Força Elétrica do Estado da Bahia. Diário Oficial do Estado da Bahia, 01.02.1920.

${ }^{85}$ O Tempo, 07.06.1919, p.1.

${ }^{86}$ Estatutos da União Gráfica Baiana. Diário O ficial do Estado da Bahia, 21.02.1920.

${ }^{87}$ Estatutos da União dos Condutores de Veículos e Classes Anexas da Bahia. Diário O ficial da Bahia, 28.05.1920.

${ }^{88}$ Estatutos da União dos Condutores de Carroças e Classes Anexas. Diário O ficial da Bahia, 25 e 27.09.1920.

${ }^{89}$ Diário da Bahia, 08.07.1919, p.2; Jornal de Notícias, 08.07.1919, p.3; 0 Imparcial, 08.07.1919, p.2.

${ }^{90} 0$ Tempo, 13.12.1919, p.2.

${ }^{91}$ Estatutos da Sociedade Centro e União Culinária. Diário O ficial do Estado da Bahia, 21.01.1921.

${ }^{92}$ A Tarde, 16.07.1920, p.2.

${ }_{93}$ Estatutos da Sociedade União Geral dos Tecelões da Bahia. Diário O ficial do Estado da Bahia, 11.09.1920.

${ }^{94} 0$ Tempo, 16.08.1919 eA O rdem, 20.08.1919, p.1; Germinal, n.2, 03.04.1920, p.8, e n.3, 01.05.1920, p.9.

${ }^{95}$ Germinal, Salvador, n.2, 03.04.1920, p.6.

960 Conservador, 31.08.1919, p.1, e 05.05.1920, p.2.

97 Sindicato de Ofícios Vários de M aré. Projeto de Estatutos. Diário O ficial do Estado da Bahia, 04.01.1921.

${ }^{98} 0$ Tempo, 15, 16, 17 e 19.07.1919; Jornal de N otícias, 28.06.1919, 15, 16, 18 e 23.07.1919; O Democrata, 16 e 22.07.1919; 0 Imparcial, 15, 16, 17, 19, 20 e 27.07.1919; Diário da Bahia, 16.07.1919; Diário de N otícias, 02.07.1919.

${ }^{99}$ A Voz do Trabalhador, Salvador, n.2, 09.10.1920, p.4, e n.24, 19.03.1921, p.1; A Tarde, 16.07.1920, p.2. 
${ }^{100}$ Sobre o assunto, ver: BATALH A, C. H . M . "Nós, Filhos da Revolução Francesa”: a imagem da revolução no movimento operário brasileiro no início do século XX. Revista Brasileira de História, São Paulo: AN PUH, v.10, n.20, p.233-49, mar.-ago. 1991.

${ }^{101}$ Germinal, Salvador, n.3, 01.05.1920, p.4. Os sindicatos representados pela Federação dos Trabalhadores Baianos no Tercei ro Congresso 0 perário Brasileiro foram: S. União dos M etalúrgicos da Bahia; Sindicato dos Pedreiros e Carpinteiros; S. União Defensora dos Sapateiros; Sindicato dos Produtores de M arcenaria; S. União dos O perários de Padaria; Liga O perária dos Alfaiates da Bahia; S. União dos M armoristas; União Gráfica Baiana; S. União dos Foguistas Terrestres da Bahia; S. Defensora dos Eletricistas; S. União Defensora dos Operários de Ferrovia; S. União dos Empregados de Bonde, Força e Luz da Bahia; S. Resistência Protetora dos O perários de São Félix e Cachoeira e União D efesa O perária de Muritiba, além do periódico socialista Germinal.

${ }^{102}$ A Tarde, 24 e 27.08.1920, p.3.

103 Jornal de Notícias, 17.08.1919, p.2.

${ }^{104}$ FRANKLIN , J. H. Raça e História. Tradução de M auro Gama. Rio de Janeiro: Rocco, 1999 , p.178.

${ }^{105}$ Os números de Germinal e A Voz do Trabalhador encontram-se no Arquivo Edgard Leuenroth (Unicamp).

${ }^{106}$ Ver os jornais A Tarde, 0 Tempo, Diário da Bahia, Diário de Notícias e Jornal de Notícias, 4 a 30.09.1919.

${ }^{107}$ Ver: Germinal, Salvador, ano I, n.1, 19.03.1920, p.8; Diário de N otícias, 28.02.1920, p.3; O Tempo, 19.03.1920, p.2; A Tarde e Diário da Bahia, jan. a mar. 1920.

${ }^{108}$ O Conservador, 15.06.1919, p.1-2; A Tarde, 18 e 19.06.1919; 0 Democrata, 21.06.1919; Diário de Notícias, 25.06.1919; Diário da Bahia, 05.07.1919.

${ }^{109}$ Ver Estatutos da Sociedade União dos Foguistas Terrestres da Bahia, Estatutos do Sindicato dos Carregadores da Bahia e Estatutos da Sociedade União de Resistência dos TrabaIhadores das Docas da Bahia, publicados no Diário O ficial do Estado da Bahia, 28.02.1920, 05.081920, 06.11.1920; Diário de Notícias, 16.10.1919, p.2, e 26.02.1921, p.1; A Tarde, 17 e 20.08.1920, p.3.

${ }^{110}$ Diário de N otícias, 26, 27, 28 e 29.01.1921 e 02.02.1921; A Voz do Trabalhador, Salvador, ano I, n.18, 05.02.1921, p.8. ARAÚJO, R. M. B. 0 batismo do trabalho: a experiência de Lindolfo Collor. Rio de Janeiro: Civilização Brasileira, 1981, p.61-8; BRANDÃO, 0. Combates e Batalhas: M emórias. São Paulo: Alfa-O mega, 1978, p.319 e 324-7.

Artigo recebido em 12/2002. Aprovado em 12/2003 